\title{
International Portfolios, Trade Imbalances and the Exchange Rate
}

\author{
Yasunori Ishii*
}

\begin{abstract}
Establishing a two-country, two-good, two-money, two-bond continuous-time dynamic portfolio model of international investor, this paper firstly demonstrates that since monies as well as bonds issued in different countries are not perfectly substitutive for each other none of them should be generally ignored in analyzing the exchange rate determination. Then, it presents the general equilibrium conditions of international asset markets considering goods trade imbalances and derives the equilibrium exchange rate. Finally it investigates the effects of large and marginal changes in money supplies, bond supplies and goods trade imbalances on the exchange rate.
\end{abstract}

\section{Introduction}

As the volume of international financial trade has increased tremendously in comparison with the amount of international goods trade, the effect of financial trade on the exchange rate has been recognized as more dominantly significant than that of goods trade. With regard to this point P. Kuori (1988) has said:

Marketable world wealth can be counted in trillions of dollars; even a small shift in asset preferences can lead to a capital transfer that is very large relative to what can be effected through the current account.

Thus, a lot of international portfolio models have been exploited to examine the roles of portfolio rules of international investors in exchange rate determination, and they have greatly contributed to developing the exchange rate theory ${ }^{1}$. However, these models have overlooked some characteristic features of a monetary economy observed in the present world.

The first significant feature overlooked in many existing international portfolio models is that nowadays both monies and bonds issued in many countries are internationally traded and thus investors can freely hold all of them in their portfolios. Therefore, it seems very curious to assume that international investors hold only either monies or bonds in their portfolios.

In practice, many investors in the main countries such as the G. 7 that have given the great

* Yokohama City University.

I wish to thank professors Takuji Shimano, Kiyoshi Ikemoto, Michihiro Ohyama, Makoto Ikema, Kazuhiro Igawa, Masayuki Hara and three anonymous referees for their useful suggestions and advices to earlier versions of this paper. 
Yasunori Ishii : International Portfolios, Trade Imbalances and the Exchange Rate

effects to the world economy participate in the international asset markets and hold both monies and bonds issued in these countries. Since the exchange rate and its expectations affect the substitutive relationships among monies and bonds it is necessary for any models examining the exchange rate to consider monies and bonds issued in different countries ${ }^{2}$.

The second essential feature of a monetary economy overlooked in almost of all existing models is that investors in a monetary economy usually evaluate their wealth expressed in terms of the money of the country where they permanently live. For example, Japanese evaluate their wealth measured in yen, Americans their wealth expressed in dollars, Germans their wealth assesed in marks and so on. Though many existing models have ignored this feature, this is crucial from both practical and theoretical points of view.

As has been indicated by J. Flemming, S. Turnovsky and M. Kemp (1977), a choice of numeraire must be careful in a model considering uncertainty. This relates to the Siegel's paradox that some results of models including random factors depend on the choice of numeraire and become undeterminable. One way to solve this difficulty is to take account of some actual behaviors of economic agents in the real world. Thus, considering the feature of a monetary economy that international investors evaluate their wealth in terms of money in their country has essential meanings.

The last significant feature of a monetary economy overlooked in lots of existing models is that the adjustment speed of the financial markets is much faster than that of the real markets. Adjustments in real decisions such as production and international goods trade require much longer time than those in financial decisions do. Moreover, data on financial variables such as the exchange rates and the asset prices are available more frequently than those on real variables such as outputs and trade imbalances. J. Frenkel (1988) has also indicated:

We do not expect any more flexible exchange rates to eliminate current account

imbalances. Data on exchange rates and interest rates are available in a much greater frequency than data on national income or on the current account.

The difference between adjustment speeds in the financial markets and in the good markets are reflected in behaviors of international trades of assets and goods. That is, while the financial asset markets attain equilibrium at each instant, the current account imbalances may last for a considerably long time unless they have a crucial effect on the world economy ${ }^{3}$. Thus, in such circumstances the asset prices including the exchange rates are determined so as to equilibrate the international asset markets at each instant given the real variables such as incomes, current account imbalances, the good prices and so on which are merely adjusted in the long run.

In what follows, I establish a more generalized model of the exchange rate determination which explicitly considers the essential features of a monetary economy mentioned above. The model also modifies the assumptions of purchasing power parity $(\mathrm{PPP})^{4}$, interest rate parity (IRP) and identical investors ${ }^{5}$. However, I do not adopt the cash-in-advance assumption proposed by $\mathrm{R}$. 
Lucas Jr. (1982) in this paper.

Nowadays residents of many countries can buy not only domestic goods but also imported goods with their domestic money in their country. Moreover, whenever they need foreign monies, they can easily get them through exchanging their domestic money in the international money (or exchange) market. They need not prepare in advance any foreign monies even in buying foreign goods within their country. Hence, the cash-in-advance assumption seems to be rather curious from an actual point of view.

In addition to the above point, the cash-in-advance assumption is also restrictive from a theoretical point of view. Though the cash-in-advance models have included both monies and bonds issued in different countries, they have excluded any money holdings stemming from speculative motives. This seems to be a serious flaw in discussing the exchange rate determination.

This paper is organized as follows. Section II presents a basic model of optimal consumptionportfolios of international investors. For investigating effectively the different roles of monies and bonds I establish a two-country, two-good, two-money, two-bond model where both monies and bonds are issued in two countries, respectively.

In Section III, I examine the effects of changes in investors' expectations on their optimal portfolio rules and modify some results which are derived in the models considering only either monies or bonds. I demonstrate that it is essentially significant to consider that investors evaluate their wealth measured in their domestic money. Furthermore, I show that monies and bonds supplied in different countries are not perfectly gross substitutive for each other respectively and that both PPP and IRP do not generally hold.

Section IV examines the exchange rate and the bond prices which equilibrate the international asset markets $^{6}$. In addition to money holdings of investors this section also considers the firms' money holdings stemming from imbalances of goods trade as a part of international money holdings. Moreover, it takes into consideration the difference between adjustment speeds of the asset markets and of the good markets. Then it analyzes the effects of changes in amounts of trade imbalances, money supplies and bond supplies in two countries on the exchange rate. As a result, it is shown that while the signs of effects of fairly large changes in these amounts on the exchange rate are definitely judged respectively, those of marginal changes in these amounts on the exchange rate become ambiguous as the volume of international asset trade grows significantly. Finally section $\mathrm{V}$ presents some concluding remarks and discusses some directions for extending the model.

\section{The Basic Model and Assumptions}

In this section I first establish a generalized model of consumption-portfolio choices of individuals who participate in both the international goods and asset markets, and then I discuss 
Yasunori Ishii : International Portfolios, Trade Imbalances and the Exchange Rate some features of their optimal consumption-portfolio rules.

As its analytical methodology of individuals' international portfolios this paper adopts the same continuous-time framework as that exploited by R. Merton (1975) and extended by D. Breeden (1979), J. Macedo (1983), R. Stulz (1984), A. Fraga (1986) et al. However, it extends their models so as to include two goods, two monies and two bonds supplied by home and foreign countries. Therefore, the goods prices, the bond prices and the exchange rate are explicitly introduced into the model.

It is here assumed that the goods prices, the bond prices and the exchange rate are all uncertain to individuals. Furthermore, it is also supposed that the expectations of these uncertain variables and the utility functions of individuals in the home country are both different from those of residents in the foreign country.

\section{A. Optimal Consumption-Portfolio Rule of the Home Investor}

In this subsection, consider an average individual in the home country consuming two goods produced in two countries and holding a variable portfolio of two monies and two bonds issued in two countries. He takes all the market prices, $\mathrm{P}_{\mathrm{i}}, \mathrm{P}_{\mathrm{b}}, \mathrm{P}_{\mathrm{b}}$ * and $\mathrm{E}$ as given, where $\mathrm{P}_{\mathrm{i}}, \mathrm{P}_{\mathrm{b}}, \mathrm{P}_{\mathrm{b}}{ }^{*}$ and $\mathrm{E}$ are the $\mathrm{i}$-th good price $(\mathrm{i}=1,2)$, the home bond price, the foreign bond price and the foreign money price expressed in terms of home money, respectively.

It is assumed that these prices are expected by the Itô type of continuous stochastic processes, i.e.,

$$
\begin{aligned}
& \mathrm{dP}_{\mathrm{i}} / \mathrm{P}_{\mathrm{i}}=\mathrm{p}_{\mathrm{i}}\left(\mathrm{P}_{\mathrm{i}}, \mathrm{P}_{\mathrm{b}}, \mathrm{P}_{\mathrm{b}}{ }^{*}, \mathrm{E}\right) \mathrm{dt}+\sigma_{\mathrm{pi}}\left(\mathrm{P}_{\mathrm{i}}, \mathrm{P}_{\mathrm{b}}, \mathrm{P}_{\mathrm{b}} * \mathrm{E}\right) \mathrm{d} \mathrm{z}_{\mathrm{pi}}, \mathrm{i}=1,2, \\
& \mathrm{dP}_{\mathrm{b}} / \mathrm{P}_{\mathrm{b}}=\mathrm{pb}_{\mathrm{b}}\left(\mathrm{P}_{\mathrm{i}}, \mathrm{P}_{\mathrm{b}}, \mathrm{P}_{\mathrm{b}} *, \mathrm{E}\right) \mathrm{dt}+\sigma_{\mathrm{pb}}\left(\mathrm{P}_{\mathrm{i}}, \mathrm{P}_{\mathrm{b}}, \mathrm{P}_{\mathrm{b}} * \mathrm{E}\right) \mathrm{d} z_{\mathrm{pb}}, \\
& \mathrm{dP}_{\mathrm{b}} * / \mathrm{P}_{\mathrm{b}}{ }^{*}=\mathrm{p}_{\mathrm{b}}^{*}\left(\mathrm{P}_{\mathrm{i}}, \mathrm{P}_{\mathrm{b}}, \mathrm{P}_{\mathrm{b}}{ }^{*}, \mathrm{E}\right) \mathrm{dt}+\sigma_{\mathrm{pb}} *\left(\mathrm{P}_{\mathrm{i}}, \mathrm{P}_{\mathrm{b}}, \mathrm{P}_{\mathrm{b}}{ }^{*}, \mathrm{E}\right) \mathrm{d} z_{\mathrm{pb}} * \\
& \mathrm{dE} / \mathrm{E}=\mathrm{e}\left(\mathrm{P}_{\mathrm{i}}, \mathrm{P}_{\mathrm{b}}, \mathrm{P}_{\mathrm{b}}{ }^{*}, \mathrm{E}\right) \mathrm{dt}+\sigma_{\mathrm{e}}\left(\mathrm{P}_{\mathrm{i}}, \mathrm{P}_{\mathrm{b}}, \mathrm{P}_{\mathrm{b}}{ }^{*}, \mathrm{E}\right) \mathrm{d} \mathrm{z}_{\mathrm{e}},
\end{aligned}
$$

where $\mathrm{p}_{\mathrm{i}}(\mathrm{i}=1,2), \mathrm{p}_{\mathrm{b}}, \mathrm{p}_{\mathrm{b}}{ }^{*}$ and $\mathrm{e}$ are the instantaneous conditional expected mean proportional changes per unit of time of $\mathrm{P}_{\mathrm{i}}(\mathrm{i}=1,2), \mathrm{P}_{\mathrm{b}}, \mathrm{P}_{\mathrm{b}} *$ and $\mathrm{E}, \sigma_{\mathrm{pi}}, \sigma_{\mathrm{pb}}, \sigma_{\mathrm{pb}} *$ and $\sigma_{\mathrm{e}}$ are the instantaneous conditional standard deviations of $\mathrm{P}_{\mathrm{i}}(\mathrm{i}=1,2), \mathrm{P}_{\mathrm{b}}, \mathrm{P}_{\mathrm{b}}{ }^{*}$ and $\mathrm{E}$, and $\mathrm{d} z_{\mathrm{pi}}(\mathrm{i}=1,2)$, $\mathrm{d} z_{\mathrm{pb}}, \mathrm{d} \mathrm{z}_{\mathrm{pb}}{ }^{*}$ and $\mathrm{d} \mathrm{z}_{\mathrm{e}}$ are the Wiener processes, respectively. It is also assumed that the instantaneous nominal interest rates of home and foreign monies are both zero.

Under the conditions given by (1), ignoring bequests and the discounting of future utility, the home investor maximizes his expected utility from time 0 to time $\mathrm{T}$ defined as ${ }^{7}$

$$
\mathrm{U}=\mathrm{E}_{0} \int_{0}^{\mathrm{T}}(1 / \gamma)\left\{\mathrm{x}_{1}(\mathrm{t})^{\alpha 1} \mathrm{x}_{2}(\mathrm{t})^{\alpha 2}\right\}^{\gamma} \mathrm{dt}=\mathrm{E}_{0} \int_{0}^{\mathrm{T}} \widetilde{\mathrm{u}}(\mathrm{t}) \mathrm{dt}
$$

where $E_{0}$ denotes expectation conditional upon the information available at time $0, x_{i}(t)$ is the amount of good i consumed at time $\mathrm{t}, \alpha_{\mathrm{i}}$ is the share of goods $\mathrm{i}$ in nominal consumption expenditure measured by home money ( $\mathrm{i}=1,2), \alpha_{1}+\alpha_{2}=1$, and $\widetilde{\mathrm{u}}$ is the instantaneous utility function with constant relative risk aversion $(1-\gamma)$, that is,

$$
\widetilde{\mathrm{u}}=(1 / \gamma) \Pi_{\mathrm{i}}{ }^{\text {air }}, \quad \mathrm{i}=1,2 .
$$

When the average home investor has a Cobb-Douglas type of instantaneous utility function 
given by (3), his real consumption expenditure $\mathrm{X}_{\mathrm{c}}$ deflated by the purchasing power of home money can be written as

$$
\mathrm{X}_{\mathrm{c}}=\mathrm{QE}_{\mathrm{N}} \text {, }
$$

where $E_{N}=\left(P_{1} x_{1}+P_{2} x_{2}\right)$ is the investor's nominal consumption expenditure expressed in terms of home money, and $\mathrm{Q}=1 / \mathrm{P}_{1}{ }^{\alpha 1} \mathrm{P}_{2}{ }^{\alpha 2}$ is the purchasing power of home money over two goods.

Similarly, the home investor's real wealth $\mathrm{W}$ is defined as the purchasing power of his nominal wealth consisting of two monies and two bonds issued in two countries,

$$
\mathrm{W}=\mathrm{Q}\left\{\mathrm{M}_{\mathrm{h}}+\mathrm{P}_{\mathrm{b}} \mathrm{B}_{\mathrm{h}}+\mathrm{E}\left(\mathrm{M}_{\mathrm{h}}{ }^{*}+\mathrm{P}_{\mathrm{b}} * \mathrm{~B}_{\mathrm{h}}{ }^{*}\right)\right\},
$$

where $\mathrm{M}_{\mathrm{h}}$ and $\mathrm{Mh}_{\mathrm{h}}{ }^{*}$ are the amounts of home and foreign monies held by the home investor, respectively, and $\mathrm{B}_{h}$ and $\mathrm{B}_{h}{ }^{*}$ are the quantities of home and foreign bonds held by the home investor, respectively.

Since the consumption of two goods and the new portfolio of monies-bonds at each instant are simultaneously chosen, the investor's instantaneous real consumption of two goods is equal to the sum of real income from reshuffling the portfolio and instantaneous flow $d Y$ of real noncapital income (which is assumed as nonstochastic in this paper),

$$
\begin{aligned}
& \mathrm{dY}-\mathrm{X}_{\mathrm{c}} \mathrm{dt}=\mathrm{dQdM_{ \textrm {h } }}+\mathrm{d}\left(\mathrm{QP}_{\mathrm{b}}\right) \mathrm{dB}_{\mathrm{h}}+\mathrm{d}(\mathrm{QE}) \mathrm{dM}_{\mathrm{h}}{ }^{*}+\mathrm{d}\left(\mathrm{QEP}_{\mathrm{b}}{ }^{*}\right) \mathrm{dB}_{\mathrm{h}}{ }^{*} \\
& +\mathrm{QdM}_{\mathrm{h}}+\left(\mathrm{QP}_{\mathrm{b}}\right) \mathrm{dB}_{\mathrm{h}}+(\mathrm{QE}) \mathrm{dM}_{\mathrm{h}}{ }^{*}+\left(\mathrm{QEP}_{\mathrm{b}}{ }^{*}\right) \mathrm{dB}_{\mathrm{h}}{ }^{*} \text {. }
\end{aligned}
$$

Thus, taking into consideration the Iô Lemma, the Wiener proceses defined in (1), $\mathrm{m}_{\mathrm{h}}+\mathrm{b}_{\mathrm{h}}+$ $\mathrm{m}_{\mathrm{h}}{ }^{*}+\mathrm{bh}_{\mathrm{h}}{ }^{*}=1$ and the investor's consumption pattern, one gets

$$
\begin{aligned}
\mathrm{dW} / \mathrm{W}= & {\left[\left(\mathrm{p}_{\mathrm{b}}-\alpha_{1} \sigma_{1 \mathrm{~b}}-\alpha_{2} \sigma_{2 \mathrm{~b}}\right) \mathrm{b}_{\mathrm{h}}+\left(\mathrm{e}-\alpha_{1} \sigma_{\mathrm{e} 1}-\alpha_{2} \sigma_{\mathrm{e} 2}\right) \mathrm{m}_{\mathrm{h}}{ }^{*}+\left\{\mathrm{e}+\mathrm{p}_{\mathrm{b}}{ }^{*}\right.\right.} \\
& \left.+\sigma_{\mathrm{eb}}{ }^{*}-\alpha_{2}\left(\sigma_{\mathrm{e} 2}+\sigma_{2 \mathrm{~b}}{ }^{*}\right)-\alpha_{1}\left(\sigma_{1 \mathrm{~b}}{ }^{*}+\sigma_{\mathrm{e} 1}\right)\right\} \mathrm{b}_{\mathrm{h}}{ }^{*}+\alpha_{1} \alpha_{2} \sigma_{12}-\alpha_{1} \mathrm{p}_{1} \\
& \left.-\alpha_{2} \mathrm{p}_{2}+\alpha_{1}\left(1+\alpha_{1}\right) \sigma_{11} / 2+\alpha_{2}\left(1+\alpha_{2}\right) \sigma_{22} / 2+\left(\mathrm{dY}-\mathrm{X}_{\mathrm{c}}\right) / \mathrm{W}\right] \mathrm{dt} \\
& +\sigma_{\mathrm{b}} \mathrm{d} z_{\mathrm{b}} \mathrm{b}_{\mathrm{h}}+\sigma_{\mathrm{e}} \mathrm{d} z_{\mathrm{e}}\left(\mathrm{m}_{\mathrm{h}}{ }^{*}+\mathrm{b}_{\mathrm{h}}{ }^{*}\right)+\sigma_{\mathrm{b}}{ }^{*} \mathrm{~d} z_{\mathrm{b}}{ }^{*} \mathrm{~b}_{\mathrm{h}}{ }^{*}-\alpha_{1} \sigma_{1} \mathrm{~d} z_{1}-\alpha_{2} \sigma_{2} \mathrm{~d} z_{2} \\
= & {\left[\mathrm{A} b_{\mathrm{h}}+\mathrm{Bm}_{\mathrm{h}}{ }^{*}+\mathrm{Cb}_{\mathrm{h}}{ }^{*}+\mathrm{D}+\left(\mathrm{dY}-\mathrm{X}_{\mathrm{c}}\right) / \mathrm{W}\right] \mathrm{dt}+\sigma_{\mathrm{b}} \mathrm{d} z_{\mathrm{b}} \mathrm{b}_{\mathrm{h}}+\sigma_{\mathrm{e}} \mathrm{d} z_{\mathrm{e}}\left(\mathrm{m}_{\mathrm{h}}{ }^{*}\right.} \\
& \left.+\mathrm{b}_{\mathrm{h}}{ }^{*}\right)+\sigma_{\mathrm{b}}{ }^{*} \mathrm{dz}_{\mathrm{b}}{ }^{*} \mathrm{bh}^{*}-\alpha_{1} \sigma_{1} \mathrm{~d} z_{1}-\alpha_{2} \sigma_{2} \mathrm{~d} z_{2},
\end{aligned}
$$

where $\mathrm{m}_{\mathrm{h}}=\mathrm{QM}_{\mathrm{h}} / \mathrm{W}, \mathrm{b}_{\mathrm{h}}=\mathrm{QP}_{\mathrm{b}} \mathrm{B}_{\mathrm{h}} / \mathrm{W}, \mathrm{m}_{\mathrm{h}}{ }^{*}=\mathrm{QEM}_{\mathrm{h}}{ }^{*} / \mathrm{W}$ and $\mathrm{b}_{\mathrm{h}}{ }^{*}=\mathrm{QEP}_{\mathrm{b}}{ }^{*} \mathrm{~B}_{\mathrm{h}}{ }^{*} / \mathrm{W}$, respectively, $\sigma_{i j}$ is the covariance between stochastic variables $i$ and $j\left(i, j=P_{1}, P_{2}, P_{b}, P_{b}{ }^{*}\right.$ and E) and $\mathrm{A}, \mathrm{B}, \mathrm{C}$ and $\mathrm{D}$ are abbreviations of the corresponding terms in the former equation, respectively, but $p \mathrm{~s}$ in the subscripts of $\sigma_{\mathrm{ij}}$ in (7) are all omitted, for example, like $\sigma_{\mathrm{ple}}=\sigma_{\mathrm{le}}$, $\sigma_{\mathrm{pbpb}} *=\sigma_{\mathrm{bb}} *, \sigma_{\mathrm{plp} 2}=\sigma_{12}$, and so on. The home investor seeks the optimal consumption and portfolio rule which maximizes his expected utility function given by (2) subject to his continuous-time stochastic budget constraint defined as $(7)^{8}$.

From (A. 4) in Appendix the optimal portfolio choices of the home investor with respect to $b_{h}$, $b_{h}{ }^{*}, m_{h}{ }^{*}$ and $m_{h}$ are obtained, respectively, by

$$
\begin{aligned}
& b_{h}=\left(\sum_{i=1}^{3} Z_{i} \Delta_{i 1}\right) / \Delta, \quad b_{h}{ }^{*}=\left(\sum_{i=1}^{3} Z_{i} \Delta_{i}\right) / \Delta, \quad m_{h}{ }^{*}=\left(\sum_{i=1}^{3} Z_{i} \Delta \Delta_{i}\right) / \Delta, \\
& m_{h}=1-b_{h}-b_{h}{ }^{*}-m_{h}{ }^{*},
\end{aligned}
$$


Yasunori Ishii : International Portfolios, Trade Imbalances and the Exchange Rate

where $\mathrm{Z}_{1}=\alpha_{1} \sigma_{1 \mathrm{~b}}+\alpha_{2} \sigma_{2 \mathrm{~b}}-\mathrm{A}\left(\mathrm{J}_{\mathrm{W}} / \mathrm{WJ} \mathrm{WW}_{\mathrm{WW}}-\Sigma\left(\mathrm{KJ}_{\mathrm{WK}} / \mathrm{WJ} \mathrm{JWW}_{\mathrm{WW}}\right) \sigma_{\mathrm{bK}}, \mathrm{Z}_{2}=\alpha_{1} \sigma_{1 \mathrm{~b}}{ }^{*}+\alpha_{2} \sigma_{2 \mathrm{~b}}{ }^{*}\right.$ $-(\mathrm{C}-\mathrm{B})\left(\mathrm{J}_{\mathrm{W}} / \mathrm{WJ} \mathrm{JWW}_{\mathrm{W}}\right)-\Sigma\left(\mathrm{KJ}_{\mathrm{WK}} / \mathrm{WJ}_{\mathrm{Ww}}\right) \sigma_{\mathrm{b}}{ }_{\mathrm{K}}, \mathrm{Z}_{3}=\alpha_{1} \sigma_{\mathrm{le}}+\alpha_{2} \sigma_{2 \mathrm{e}}-\mathrm{B}\left(\mathrm{J}_{\mathrm{W}} / \mathrm{WJ}_{\mathrm{WW}}\right)-\Sigma\left(\mathrm{KJ}_{\mathrm{WK}} /\right.$ $\left.\mathrm{WJ}_{\mathrm{WW}}\right) \sigma_{\mathrm{eK}}, \Delta$ is the determinant of the variance-covariance matrix in (A. 4) which is expressed as

$$
\Delta=\left|\begin{array}{ccc}
\sigma_{\mathrm{bb}} & \sigma_{\mathrm{b}}{ }_{\mathrm{b}} & \sigma_{\mathrm{eb}} \\
\sigma_{\mathrm{bb}}{ }^{*} & \sigma_{\mathrm{b}}{ }^{*}{ }^{*} & \sigma_{\mathrm{eb}}{ } \\
\sigma_{\mathrm{be}} & \sigma_{\mathrm{b}}{ }^{*} \mathrm{e} & \sigma_{\mathrm{ee}}
\end{array}\right|
$$

and $\Delta_{\mathrm{ij}}(\mathrm{i}, \mathrm{j}=1,2,3)$ are the cofactors of the element in the $i$ th row and $j$ th columm of $\Delta$.

Since the relative risk tolerance of the home investor is defined as $T_{R}=-J_{W} / W J_{W w}$ and the elasticities of the Bellman function with respect to $\mathrm{K}\left(=\mathrm{P}_{1}, \mathrm{P}_{2}, \mathrm{P}_{\mathrm{b}}, \mathrm{P}_{\mathrm{b}}{ }^{*}, \mathrm{E}\right)$ are expressed as $\mathrm{U}_{\mathrm{WK}}=\left(\mathrm{K} / \mathrm{J}_{\mathrm{W}}\right)\left(\partial_{\mathrm{JW}} / \partial \mathrm{K}\right), Z_{\mathrm{i}}(\mathrm{i}=1,2,3)$ are rewritten, respectively, as

$$
\begin{aligned}
& \mathrm{Z}_{1}=\left(\alpha_{1} \sigma_{1 \mathrm{~b}}+\alpha_{2} \sigma_{2 \mathrm{~b}}\right)\left(1-\mathrm{T}_{\mathrm{R}}\right)+\left(\mathrm{p}_{\mathrm{b}}+\sum_{\mathrm{K}} \mathrm{U}_{\mathrm{WK}} \sigma_{\mathrm{Kb}}\right) \mathrm{T}_{\mathrm{R}}, \\
& \mathrm{Z}_{2}=\left(\alpha_{1} \sigma_{1 \mathrm{~b}}{ }^{*}+\alpha_{2} \sigma_{2 \mathrm{~b}}{ }^{*}\right)\left(1-\mathrm{T}_{\mathrm{R}}\right)+\left(\mathrm{pb}^{*}+\sigma_{\mathrm{eb}} * \sum_{\mathrm{K}} \mathrm{U}_{\mathrm{WK}} \sigma_{\mathrm{Kb}}{ }^{*} \mathrm{~T}_{\mathrm{R}},\right. \\
& \mathrm{Z}_{3}=\left(\alpha_{1} \sigma_{1 \mathrm{e}}+\alpha_{2} \sigma_{2 \mathrm{e}}\right)\left(1-\mathrm{T}_{\mathrm{R}}\right)+\left(\mathrm{e}+\sum_{\mathrm{K}} \mathrm{U}_{\mathrm{WK}} \sigma_{\mathrm{eK}}\right) \mathrm{T}_{\mathrm{R}} .
\end{aligned}
$$

Hence it is immediately obvious from (1), (8) and (9) that the optimal portfolio rule of the home investor generally depends on his relative risk tolerance, his consumption pattern, the state variables and his expectations of these state variables. Though it is very interesting to analyze the investor's portfolio rules and to make clear their characteristic features, the more detailed examinations about the home investor's portfolio rule given by (1), (8) and (9) will be presented in section III, together with those of the foreign investor's portfolio rule derived in the next subsection.

\section{B. Optimal Consumption-Portfolio Rule of the Foreign Investor}

Suppose an average foreign investor consuming two goods produced in two countries and holding a variable portfolio of two monies and two bonds issued in two countries. Thus, he also faces five kinds of the market prices, i.e., the consumption-good prices, $\mathrm{P}_{1}{ }^{*}$ and $\mathrm{P}_{2}{ }^{*}$, the bond prices, $\mathrm{P}_{\mathrm{b}}$ and $\mathrm{P}_{\mathrm{b}}{ }^{*}$, and the exchange rate, $\mathrm{E}$, where $\mathrm{P}_{\mathrm{i}}{ }^{*}$ is the price of a consumption good $\mathrm{i}$ in terms of foreign money( $i=1,2)$ and the other prices are the same as those used in the previous subsection. He also takes all these prices as uncertain and given.

It is also assumed that the market prices are all expected by the Itô type of continuous stochastic processes which are different from those of the home investor,

$$
\begin{aligned}
& \mathrm{dP}_{\mathrm{i}}^{*} / \mathrm{P}_{\mathrm{i}}^{*}=\mathrm{p}_{\text {if }}\left(\mathrm{P}_{\mathrm{i}}^{*}, \mathrm{P}_{\mathrm{b}}, \mathrm{P}_{\mathrm{b}}^{*}, \mathrm{E}\right) \mathrm{dt}+\sigma_{\text {pif }}\left(\mathrm{P}_{1}^{*}, \mathrm{P}_{\mathrm{b}}, \mathrm{P}_{\mathrm{b}}^{*}, \mathrm{E}\right) \mathrm{d} \mathrm{z}_{\text {pif }}, \quad \mathrm{i}=1,2, \\
& \mathrm{dP}_{\mathrm{b}} / \mathrm{P}_{\mathrm{b}}=\mathrm{pbf}_{\mathrm{b}}\left(\mathrm{P}_{\mathrm{i}}^{*}, \mathrm{P}_{\mathrm{b}}, \mathrm{P}_{\mathrm{b}}^{*}, \mathrm{E}\right) \mathrm{dt}+\sigma_{\mathrm{pbf}}\left(\mathrm{P}_{\mathrm{i}}^{*}, \mathrm{P}_{\mathrm{b}}, \mathrm{P}_{\mathrm{b}}^{*}, \mathrm{E}\right) \mathrm{d} z_{\mathrm{pbf}}, \\
& \mathrm{dP}_{\mathrm{b}}{ }^{*} / \mathrm{P}_{\mathrm{b}} *=\mathrm{pb}_{\mathrm{f}}{ }_{\mathrm{f}}\left(\mathrm{P}_{\mathrm{i}}^{*}, \mathrm{P}_{\mathrm{b}}, \mathrm{P}_{\mathrm{b}}{ }^{*}, \mathrm{E}\right) \mathrm{dt}+\sigma_{\mathrm{pb}}{ }_{\mathrm{f}}\left(\mathrm{P}_{\mathrm{i}}^{*}, \mathrm{P}_{\mathrm{b}}, \mathrm{P}_{\mathrm{b}}{ }^{*}, \mathrm{E}\right) \mathrm{d} \mathrm{pbb}_{\mathrm{f}}{ }_{\mathrm{f}} \\
& d E / E=e_{f}\left(P_{i}^{*}, P_{b}, P_{b}^{*}, E\right) d t+\sigma_{\text {ef }}\left(P_{i}^{*}, P_{b}, P_{b}^{*}, E\right) d z_{e f} .
\end{aligned}
$$

In (10) and hereafter notations including $\mathrm{f}$ in subscripts denote those of the foreign investor.

The foreign investor maximizes his expected utility from time 0 to time $\mathrm{T}$ defined as

$$
\mathrm{U}_{\mathrm{f}}=\mathrm{E}_{0 \mathrm{f}} \int_{0}^{\mathrm{T}}(1 / \mu)\left\{\mathrm{x}_{1 \mathrm{f}}(\mathrm{t})^{\beta 1} \mathrm{x}_{2 \mathrm{f}}(\mathrm{t})^{\beta 2}\right\}^{\mu} \mathrm{dt}=\mathrm{E}_{0 \mathrm{f}} \int_{0}^{\mathrm{T}} \widetilde{\mathrm{u}}_{\mathrm{f}}(\mathrm{t}) \mathrm{dt}
$$


where $\beta_{\mathrm{i}}$ is the share of good $\mathrm{i}(=1,2)$ in nominal consumption expenditure measured by foreign money, $\beta_{1}+\beta_{2}=1$ holds by definition, and $(1-\mu)$ is the relative risk aversion of the foreign investor which is constant in our model.

According to the same way as just adopted in the previous subsection the foriegn investor's real consumption expenditure $\mathrm{X}_{\mathrm{cf}}$ deflated by the purchasing power of foreign money is given by

$$
\mathrm{X}_{\mathrm{cf}}=\mathrm{Q}^{*} \mathrm{E}_{\mathrm{Nf}},
$$

where $\mathrm{E}_{\mathrm{Nf}}=\left(\mathrm{P}_{1}{ }^{*} \mathrm{x}_{1 \mathrm{f}}+\mathrm{P}_{2}{ }^{*} \mathrm{x}_{2 \mathrm{f}}\right)$ is the foreign investor's nominal consumption expenditure expressed in terms of foreign money, and $\mathrm{Q}^{*}=1 / \mathrm{P}_{1}{ }^{\beta 1} \mathrm{P}_{2}{ }^{\beta 2}$ is the purchasing power of foreign money over two goods in the foreign country.

Taking into consideration that the foreign investor also holds two kinds of monies and two kinds of bonds issued in the two countries and that he usually evaluates his own wealth measured in terms of foreign money, his real wealth $\mathrm{W}_{\mathrm{f}}$ deflated by the purchasing power of foreign money is defined as

$$
\mathrm{W}_{\mathrm{f}}=\mathrm{Q}^{*}\left\{\left(\mathrm{M}_{\mathrm{f}}+\mathrm{P}_{\mathrm{b}} \mathrm{B}_{\mathrm{f}}\right) / \mathrm{E}+\left(\mathrm{M}_{\mathrm{f}} *+\mathrm{P}_{\mathrm{b}} * \mathrm{~B}_{\mathrm{f}}^{*}\right)\right\},
$$

where $\mathrm{M}_{\mathrm{f}}$ and $\mathrm{M}_{\mathrm{f}}^{*}$ are the amounts of home and foreign monies demanded by the foreign investor and $\mathrm{B}_{\mathrm{f}}$ and $\mathrm{B}_{\mathrm{f}}$ * are the quantities of home and foreign bonds held by him, respectively.

If $\mathrm{PPP}$ holds, that is, $\mathrm{E}=\mathrm{Q}^{*} / \mathrm{Q}$ is true, then (13) is rewritten as

$$
\mathrm{W}_{\mathrm{f}}=\mathrm{Q}\left\{\left(\mathrm{M}_{\mathrm{f}}+\mathrm{P}_{\mathrm{b}} \mathrm{B}_{\mathrm{f}}\right)+\mathrm{E}\left(\mathrm{M}_{\mathrm{f}} *+\mathrm{P}_{\mathrm{b}} * \mathrm{~B}_{\mathrm{f}}^{*}\right)\right\} .
$$

In this case, replacing the subscript $f$ in $(13)^{\prime}$ with $h,(13)^{\prime}$ equals (5). But this is not the case in the present paper since PPP is not supposed. Moreover, if the law of one price, i.e., $\mathrm{P}_{\mathrm{i}}=$ $\mathrm{EP}_{\mathrm{i}}^{*}(\mathrm{i}=1,2)$ holds, then $\mathrm{Q}^{*}=\mathrm{P}_{1}{ }^{* 1} \mathrm{P}_{2}{ }^{\beta 2}=\mathrm{EP}_{1}{ }^{\beta 1} \mathrm{P}_{2}{ }^{\beta 2}$ holds. Therefore, denoting $\tilde{\mathrm{Q}}=$ $\mathrm{P}_{1}^{\beta 1} \mathrm{P}_{2}^{\beta 2}$, (13) is rewritten as

$$
\mathrm{W}_{\mathrm{f}}=\tilde{\mathrm{Q}}\left\{\left(\mathrm{M}_{\mathrm{f}}+\mathrm{P}_{\mathrm{b}} \mathrm{B}_{\mathrm{f}}\right)+\mathrm{E}\left(\mathrm{M}_{\mathrm{f}}^{*}+\mathrm{P}_{\mathrm{b}} * \mathrm{~B}_{\mathrm{f}}^{*}\right)\right\} .
$$

Hence, once again, replacing the subscript $f$ and $\widetilde{Q}$ in $(13)^{\prime \prime}$ with $h$ and $Q$, respectively, (13) "' is equal to (5). However, it is easily shown from $(13)^{\prime}$ and $(13)^{\prime \prime}$ that the law of one price does not generally imply PPP except for the case where the consumption patterns of the home and foreign investors are the same, that is, $\alpha_{\mathrm{i}}=\beta_{\mathrm{i}}(\mathrm{i}=1,2)$ holds. In this paper it is not supposed that the law of one price always holds.

Now, adopting the new notation, $\widetilde{\mathrm{E}}=1 / \mathrm{E}$, (13) becomes

$$
\mathrm{W}_{\mathrm{f}}=\mathrm{Q}^{*}\left\{\left(\mathrm{M}_{\mathrm{f}} *+\mathrm{P}_{\mathrm{b}} * \mathrm{~B}_{\mathrm{f}}^{*}\right)+\widetilde{\mathrm{E}}\left(\mathrm{M}_{\mathrm{f}}+\mathrm{P}_{\mathrm{b}} \mathrm{B}_{\mathrm{f}}\right)\right\} \text {. }
$$

Clearly, since $(13)^{\prime \prime \prime}$ includes $(13)^{\prime}$ and $(13)^{\prime \prime}$ as special cases, the arguments based on (13)'" would generalize those based on the PPP assumption and/or on the assumption of the law of one price.

Comparing (13)'" with (5), one would find once again that the definition of the real wealth of the foreign investor is quite symmetrical with that of the home investor when one can recognize that $\mathrm{M}_{\mathrm{h}}, \mathrm{B}_{\mathrm{h}}, \mathrm{M}_{\mathrm{f}}, \mathrm{B}_{\mathrm{f}}, \mathrm{Q}$ and $\mathrm{E}$ in (5) are corresponding to $\mathrm{M}_{\mathrm{f}}{ }^{*}, \mathrm{~B}_{\mathrm{f}}{ }^{*}, \mathrm{M}_{\mathrm{h}}{ }^{*}, \mathrm{~B}_{\mathrm{h}}{ }^{*}, \mathrm{Q}^{*}$ and $\widetilde{\mathrm{E}}$ in $(13)^{\prime \prime \prime}$, respectively. In this case, from (10) and the Itô Lemma one gets 
Yasunori Ishii : International Portfolios, Trade Imbalances and the Exchange Rate

$$
\mathrm{d} \widetilde{\mathrm{E}} / \widetilde{\mathrm{E}}=-\mathrm{dE} / \mathrm{E}+(\mathrm{dE} / \mathrm{E})^{2}=\left(\sigma_{\text {eef }}-\mathrm{e}_{\mathrm{f}}\right) \mathrm{dt}-\sigma_{\text {ef }} \mathrm{d} z_{\text {ef }} .
$$

Furthermore, it is also shown, comparing (10) and (11) with (1) and (2), respectively, that both the expectation pattern and the utility function of the foreign investor are similar to those of the home investor. Therefore, it is quite obvious that the foreign investor's optimal portfolio rule is derived in the same way as that used in deriving the home investor's optimal portfolio rule in the previous subsection, that is, the foreign investor's optimal portfolio choices are given by

$$
\begin{aligned}
& \mathrm{b}_{\mathrm{f}}^{*}=\left(\sum_{\mathrm{i}=1} Z_{\mathrm{if}} \Delta_{\mathrm{ilf}}\right) / \Delta_{\mathrm{f}}, \quad \mathrm{b}_{\mathrm{f}}=\left(\sum_{\mathrm{i}=1} Z_{\mathrm{if}} \Delta_{\mathrm{i} 2 \mathrm{f}}\right) / \Delta \mathrm{f}, \quad \mathrm{m}_{\mathrm{f}}=\left(\sum_{\mathrm{i}=1} Z_{\mathrm{if}} \Delta_{\mathrm{i} 3 \mathrm{f}}\right) / \Delta \mathrm{f}, \\
& \mathrm{m}_{\mathrm{f}}{ }^{*}=1-\mathrm{b}_{\mathrm{f}}^{*}-\mathrm{b}_{\mathrm{f}}-\mathrm{m}_{\mathrm{f}},
\end{aligned}
$$

where $\mathrm{m}_{\mathrm{f}}^{*}=\mathrm{Q}^{*} \mathrm{M}_{\mathrm{f}}^{*} / \mathrm{W}_{\mathrm{f}}, \mathrm{b}_{\mathrm{f}}^{*}=\mathrm{Q}^{*} \mathrm{P}_{\mathrm{b}}{ }^{*} \mathrm{~B}_{\mathrm{f}} * / \mathrm{W}_{\mathrm{f}}, \mathrm{m}_{\mathrm{f}}=\mathrm{Q}^{*} \widetilde{\mathrm{E}} \mathrm{M}_{\mathrm{f}} / \mathrm{W}_{\mathrm{f}}, \mathrm{b}_{\mathrm{f}}=\mathrm{Q}^{*} \widetilde{\mathrm{E}} \mathrm{P}_{\mathrm{b}} \mathrm{B}_{\mathrm{f}} / \mathrm{W}_{\mathrm{f}}$,

$$
\begin{aligned}
& \Delta_{\mathrm{f}}=\left|\begin{array}{ccc}
\sigma_{\mathrm{b}}{ }_{\mathrm{b}}{ }_{\mathrm{f}} & \sigma_{\mathrm{bb}} *_{\mathrm{f}} & \sigma_{\mathrm{eb}}{ }_{\mathrm{f}} \\
\sigma_{\mathrm{b}}{ }_{\mathrm{bf}} & \sigma_{\mathrm{bbf}} & \sigma_{\text {ebf }} \\
\sigma_{\mathrm{b}}{ }_{\mathrm{ef}} & \sigma_{\text {bef }} & \sigma_{\text {eef }}
\end{array}\right|, \\
& \mathrm{Z}_{1 \mathrm{f}}=\left(\beta_{1} \sigma_{1}{ }_{\mathrm{b}}{ }_{\mathrm{f}}+\beta_{2} \sigma_{2}{ }_{\mathrm{b}}{ }^{{ }_{\mathrm{f}}}\right)\left(1-\mathrm{T}_{\mathrm{Rf}}\right)+\left(\mathrm{pb}_{\mathrm{f}}{ }_{\mathrm{f}}+\sum_{\mathrm{K}} \mathrm{U}_{\mathrm{WKf}} \tilde{\sigma}_{\mathrm{Kb}}{ }^{*}\right) \mathrm{T}_{\mathrm{Rf}}, \\
& Z_{2 \mathrm{f}}=\left(\beta_{1} \sigma_{1}{ }_{\mathrm{bf}}+\beta_{2} \sigma_{2}{ }_{\mathrm{bf}}\right)\left(1-\mathrm{T}_{\mathrm{Rf}}\right)+\left(\mathrm{pbf}-\sigma_{\mathrm{ebf}}+\sum_{\mathrm{K}} \mathrm{U}_{\mathrm{WKf}} \tilde{\sigma}_{\mathrm{Kb}}\right) \mathrm{T}_{\mathrm{Rf}}, \\
& Z_{3 \mathrm{f}}=-\left(\beta_{1} \sigma_{1}{ }^{*}{ }_{\mathrm{ef}}+\beta_{2} \sigma_{2}{ }^{*}{ }_{\mathrm{ef}}\right)\left(1-\mathrm{T}_{\mathrm{Rf}}\right)+\left(\sigma_{\mathrm{eef}}-\mathrm{e}_{\mathrm{f}}+\sum_{\mathrm{K}} \mathrm{U}_{\mathrm{WK}} \tilde{\sigma}_{\mathrm{eK}}\right) \mathrm{T}_{\mathrm{Rf}}, \\
& \left(\because \tilde{\sigma}_{\mathrm{eK}}=-\sigma_{\mathrm{eKf}} \text { for } \mathrm{K} \neq \mathrm{e}, \tilde{\sigma}_{\mathrm{ee}}=\sigma_{\mathrm{ee}}, \tilde{\sigma}_{\mathrm{Kb}} *=\sigma_{\mathrm{Kb}} *_{\mathrm{f}}, \tilde{\sigma}_{\mathrm{Kb}}=\sigma_{\mathrm{Kbf}}\right) \text {. }
\end{aligned}
$$

It is shown from (8) and (15) that the optimal portfolio choices of the foreign investor are quite different from those of the home investor though their derivations are similar to each other. This is one of the features stemmed from the fact that international investors evaluate their wealth by their domestic money. The other features stemming from different money choices are discussed in the next section.

\section{Risk Aversion, Expectations and the Optimal Portfolio Rules}

In this section, to save space I mainly examine the effects of the home investor's risk tolerance and his expectations of the state variables on his optimal portfolio choices. However, I also refer to the features of optimal portfolio choices of the foreign investor in discussing the differences between the optimal portfolio choices of the home and the foreign investors.

If the risk tolerance, $T_{R}$, of the home investor is zero, his optimal portfolio choices of $b_{h}, b_{h}{ }^{*}$, $\mathrm{m}_{\mathrm{h}}{ }^{*}$ and $\mathrm{m}_{\mathrm{h}}$ are, from $(8)$ and $(9)$, given by

$$
\begin{array}{ll}
\mathrm{b}_{\mathrm{h}} & =\left(\Sigma Z_{\mathrm{i} \Delta \mathrm{i} 1}\right) / \Delta, \\
\mathrm{b}_{\mathrm{h}}{ }^{*} & =\left(\Sigma Z_{\mathrm{i} \Delta \mathrm{i} 2}\right) / \Delta, \\
\mathrm{m}_{\mathrm{h}}{ }^{*} & =\left(\Sigma Z_{\mathrm{i}} \mathrm{i}_{\mathrm{i} 3}\right) / \Delta, \text { and } \\
\mathrm{m}_{\mathrm{h}} & =1-\mathrm{b}_{\mathrm{h}}-\mathrm{b}_{\mathrm{h}}{ }^{*}-\mathrm{m}_{\mathrm{h}}{ }^{*}, \quad \mathrm{i}=1,2,3,
\end{array}
$$

where $Z_{1}=\left(\alpha_{1} \sigma_{1 \mathrm{~b}}+\alpha_{2} \sigma_{2 \mathrm{~b}}\right), Z_{2}=\left(\alpha_{1} \sigma_{1 \mathrm{~b}}{ }^{*}+\alpha_{2} \sigma_{2 \mathrm{~b}}{ }^{*}\right)$ and $Z_{3}=\left(\alpha_{1} \sigma_{1 \mathrm{e}}+\alpha_{2} \sigma_{2 \mathrm{e}}\right)$. Therefore, it is clear in the case of $T_{R}=0$ that the home investor's optimal portfolio rule is equivalent to the minimum variance portfolio rule which minimizes the instantaneous conditional variance of $\mathrm{dW} / \mathrm{W}$ and is independent of the state variables, $\mathrm{P}_{1}, \mathrm{P}_{2}, \mathrm{P}_{\mathrm{b}}, \mathrm{P}_{\mathrm{b}}{ }^{*}$ and $\mathrm{E}$ as well as their expected mean 
proportional changes per unit time, $\mathrm{p}_{1}, \mathrm{p}_{2}, \mathrm{p}_{\mathrm{b}}, \mathrm{p}_{\mathrm{b}}{ }^{*}$ and $\mathrm{e}$.

On the other hand, if $T_{R}$ is unity, the home investor's portfolio rule is reduced, from (8) and (9), as

$$
\begin{array}{ll}
\mathrm{b}_{\mathrm{h}} & =\left(\Sigma Z_{\mathrm{i} \Delta \mathrm{i} 1}\right) / \Delta, \\
\mathrm{b}_{\mathrm{h}}{ }^{*} & =\left(\Sigma Z_{\mathrm{i} \Delta \mathrm{i} 2}\right) / \Delta, \\
\mathrm{m}_{\mathrm{h}}{ }^{*} & =\left(\Sigma Z_{\mathrm{i} \Delta \mathrm{i} 3}\right) / \Delta, \text { and } \\
\mathrm{m}_{\mathrm{h}} & =1-\mathrm{b}_{\mathrm{h}}-\mathrm{b}_{\mathrm{h}}{ }^{*}-\mathrm{m}_{\mathrm{h}}{ }^{*}, \quad \mathrm{i}=1,2,3,
\end{array}
$$

where $Z_{1}=\left(\mathrm{pb}_{\mathrm{b}}+\Sigma \mathrm{U}_{\mathrm{WK}} \sigma_{\mathrm{Kb}}\right), Z_{2}=\left(\mathrm{p}^{*}+\sigma_{\mathrm{eb}}{ }^{*}+\Sigma \mathrm{U}_{\mathrm{WK}} \sigma_{\mathrm{Kb}}{ }^{*}\right)$ and $Z_{3}=\left(\mathrm{e}+\Sigma \bigcup_{\mathrm{WK}} \sigma_{\mathrm{eK}}\right)$. Hence, it is shown in this case that the optimal portfolio rule of the home investor is equal to the logarithmic portfolio rule and that his portfolio choices are insensitive to both his consumption pattern, $\alpha_{\mathrm{i}}(\mathrm{i}=1,2)$ and the expected mean proportional changes per unit time of $\mathrm{P}_{\mathrm{i}}$, i.e., $\mathrm{p}_{1}$ and p2.

The above arguments demonstrate that the home investor's portfolio rule is generally expressed as a weighted average of the minimum variance portfolio rule and the logarithmic portfolio rule as W. Bransson and D. Henderson (1985) have indicated by using a special one of our model. Therefore, as the investor's risk tolerance approaches unity (zero), his portfolio rule also does the logarithmic portfolio rule (the minimum variance portfolio rule).

Since the home investor's portfolio rule depends on all of his consumption pattern, his risk tolerance, his conditional instantaneous expectations of the state variables except for $\mathrm{p}_{1}$ and $\mathrm{p}_{2}$, and the current state variables, if the bonds issued in two countries are perfectly gross substitutive for each other, $\partial \mathrm{b}_{\mathrm{h}} / \partial \mathrm{p}_{\mathrm{b}}=-\partial \mathrm{b}_{\mathrm{h}}{ }^{*} / \partial \mathrm{p}_{\mathrm{b}}$ and $/$ or $\partial \mathrm{b}_{\mathrm{h}} / \partial \mathrm{p}_{\mathrm{b}}{ }^{*}=-\partial \mathrm{b}_{\mathrm{h}}{ }^{*} / \partial \mathrm{p}_{\mathrm{b}}{ }^{*}$ must be true. So I now examine these relations.

Differentiating respectively $b_{h}$ and $b_{h}{ }^{*}$ in (8) with respect to $\mathrm{pb}_{b}$ and $\mathrm{p}^{*}$, and taking the Cauchy-Schwarz inequality into consideration, one gets

$$
\begin{aligned}
\partial \mathrm{b}_{\mathrm{h}} / \partial \mathrm{p}_{\mathrm{b}} & =\Delta_{11} \mathrm{~T}_{\mathrm{R}} / \Delta>0, \\
\partial \mathrm{b}_{\mathrm{h}}{ }^{*} / \partial \mathrm{p}_{\mathrm{b}}{ }^{*} & =\Delta_{22} \mathrm{~T}_{\mathrm{R}} / \Delta>0, \\
\partial \mathrm{b}_{\mathrm{h}}{ }^{*} / \partial \mathrm{p}_{\mathrm{b}} & =\Delta_{12} \mathrm{~T}_{\mathrm{R}} / \Delta>(<) 0 \text { as } \Delta 12>(<) 0, \\
\partial \mathrm{b}_{\mathrm{h}} / \partial \mathrm{p}_{\mathrm{b}}{ }^{*} & =\Delta_{21} \mathrm{~T}_{\mathrm{R}} / \Delta>(<) 0 \text { as } \Delta 21>(<) 0 .
\end{aligned}
$$

Thus, only the signs of $\partial \mathrm{b}_{\mathrm{h}} / \partial \mathrm{p}_{\mathrm{b}}$ and $\partial \mathrm{b}_{\mathrm{h}}{ }^{*} / \partial \mathrm{p}_{\mathrm{b}}{ }^{*}$ are determined as positive since $\Delta, \Delta_{11}$ and $\Delta 22$ are positive, which implies that an increase in the instantaneous conditional expected mean proportional change per unit time of the home(foreign) bond price raises home(foreign) bond holdings of the home investor, and vice versa. However, the signs of $\partial \mathrm{b}_{\mathrm{h}} * / \partial \mathrm{p}_{\mathrm{b}}$ and $\partial \mathrm{b}_{\mathrm{h}} / \partial \mathrm{p}_{\mathrm{b}} *$ are both ambiguous due to the equivocation of the signs of $\Delta 12$ and $\Delta 21$. Moreover, it is shown that the effects of a change in $\mathrm{pb}_{\mathrm{b}}\left(\mathrm{pb}^{*}\right)$ on $\mathrm{b}_{\mathrm{h}}$ and $\mathrm{b}_{\mathrm{h}}{ }^{*}$ are different from each other since $\Delta_{11} \neq \Delta_{12}$ $\left(\Delta_{22} \neq \Delta_{21}\right)$ holds in general. Thus, the home and foreign bonds are not perfectly gross substitutive for each other except for a special case of $T_{R}=0$ where both $b_{h}$ and $b_{h}{ }^{*}$ are insensitive to $\mathrm{p}_{\mathrm{b}}\left(\mathrm{p}_{\mathrm{b}}{ }^{*}\right)$. 
Yasunori Ishii : International Portfolios, Trade Imbalances and the Exchange Rate

It is also shown from (8) that monies issued in two countries are not also perfectly gross substitutive for each other. Differentiating $\mathrm{m}_{\mathrm{h}}{ }^{*}$ and $\mathrm{m}_{\mathrm{h}}$ in (8) with respect to $\mathrm{e}$ and taking account of the Cauchy-Schwarz inequality one obtains

$$
\begin{aligned}
\partial \mathrm{m}_{\mathrm{h}}{ }^{*} / \partial \mathrm{e} & =\Delta_{33} \mathrm{~T}_{\mathrm{R}} / \Delta>0, \\
\partial \mathrm{m}_{\mathrm{h}} / \partial \mathrm{e} & =-\left(\Delta_{31}+\Delta_{32}+\Delta_{33}\right) \mathrm{T}_{\mathrm{R}} / \Delta .
\end{aligned}
$$

Obviously an increase in the expected mean proportional change per unit time of the exchange rate increases the foreign money holdings of the home investor and vice versa. However the sign of the second equation of (20) is generally ambiguous and thus the absolute value of the right side of $\partial m_{h}{ }^{*} / \partial e$ is different from that of $\partial m_{h} / \partial e$ except for a special case of $T_{R}=0$ where both $\mathrm{m}_{\mathrm{h}}{ }^{*}$ and $\mathrm{m}_{\mathrm{h}}$ are insensitive to e.

In the present model considering uncertainty of the good prices, the bond prices and the exchange rate, the risk premium in international portfolios is defined as the expected return differential. Therefore, the risk premium of the home investor is given by

$$
\begin{aligned}
\mathrm{pb}_{\mathrm{b}}- & \mathrm{p}_{\mathrm{b}} *-\mathrm{e} \\
= & \alpha_{1}\left(1+\mathrm{R}_{\mathrm{R}}\right)\left(\sigma_{1 \mathrm{~b}}-\sigma_{1 \mathrm{~b}} *-\sigma_{1 \mathrm{e}}\right)+\alpha_{2}\left(1+\mathrm{R}_{\mathrm{R}}\right)\left(\sigma_{2 \mathrm{~b}}-\sigma_{2 \mathrm{~b}} *-\sigma_{2 \mathrm{e}}\right) \\
& -\mathrm{R}_{\mathrm{R}}\left\{\mathrm{b}_{\mathrm{h}}\left(\sigma_{\mathrm{bb}}-\sigma_{\mathrm{bb}} *-\sigma_{\mathrm{be}}\right)+\mathrm{b}_{\mathrm{h}} *\left(\sigma_{\mathrm{bb}} *-\sigma_{\mathrm{b}}{ }^{*}{ }^{*}-\sigma_{\mathrm{eb}}{ }^{*}\right)\right. \\
& \left.+\left(\mathrm{m}_{\mathrm{h}} *+\mathrm{b}_{\mathrm{h}}\right)\left(\sigma_{\mathrm{eb}}-\sigma_{\mathrm{eb}}{ }^{*}-\sigma_{\mathrm{ee}}\right)\right\}+\sum_{\mathrm{K}} \mathrm{U}_{\mathrm{KW}}\left(\sigma_{\mathrm{bK}}-\sigma_{\mathrm{b}}{ }_{\mathrm{K}}-\sigma_{\mathrm{eK}}\right),
\end{aligned}
$$

where $R_{R}\left(=1 / T_{R}\right)$ is the relative risk aversion of the home investor. On the other hand, the risk premium of the foreign investor is given by

$$
\begin{aligned}
& \mathrm{pb}_{\mathrm{b}}{ }_{\mathrm{f}}-\mathrm{p}_{\mathrm{bf}}+\mathrm{e}_{\mathrm{f}} \\
& =\beta_{1}\left(1+\mathrm{R}_{\mathrm{Rf}}\right)\left(\sigma_{1}{ }^{*}{ }_{\mathrm{b}} \mathrm{f}_{\mathrm{f}}-\sigma_{1}{ }_{\mathrm{bff}}+\sigma_{1}{ }^{*}{ }_{\mathrm{ef}}\right)+\beta_{2}\left(1+\mathrm{R}_{\mathrm{Rf}}\right)\left(\sigma_{2}{ }^{*}{ }_{\mathrm{b}}{ }_{\mathrm{f}}-\sigma_{2}{ }^{*} \mathrm{bf}\right. \\
& \left.+\sigma_{2}{ }^{*}{ }_{\mathrm{ef}}\right)-\mathrm{R}_{\mathrm{Rf}}\left\{\mathrm{b}_{\mathrm{f}}{ }^{*}\left(\sigma_{\mathrm{b}}{ }^{*}{ }_{\mathrm{b}}{ }_{\mathrm{f}}-\sigma_{\mathrm{b}}{ }_{\mathrm{bf}}+\sigma_{\mathrm{b}}{ }_{\mathrm{eff}}\right)+\mathrm{b}_{\mathrm{f}}\left(\sigma_{\mathrm{b}}{ }_{\mathrm{bf}}-\sigma_{\mathrm{bbf}}+\sigma_{\mathrm{eb}}{ }_{\mathrm{f}}\right)\right. \\
& \left.+\left(\mathrm{m}_{\mathrm{f}}+\mathrm{b}_{\mathrm{f}}\right)\left(\sigma_{\mathrm{ebf}}-\sigma_{\mathrm{eb}}{ }_{\mathrm{f}}-\sigma_{\mathrm{eef}}\right)\right\}+\sigma_{\mathrm{eef}}+\sum_{\mathrm{K}} \mathrm{L}_{\mathrm{KWf}}\left(\sigma_{\mathrm{b}}{ }^{*}{ }_{\mathrm{Kf}}-\tilde{\sigma}_{\mathrm{b}}{ }_{\mathrm{Kf}}-\sigma_{\mathrm{eKf}}\right),
\end{aligned}
$$

where $\mathrm{R}_{\mathrm{Rf}}\left(=1 / \mathrm{T}_{\mathrm{Rf}}\right)$ is the relative risk aversion of the foreign investor.

If the bonds issued in two countries are perfectly gross substitutive for each other and if the international asset markets are perfectly competitive, then both the right sides of (21) and (22) must be zero, and thus the more generalized interest rate parity including monies and bonds issued in two countries would be true. However, there is no guarantee that both the right sides of (21) and (22) are always zero. Hence, interest rate parity, i.e., IRP, would not generally hold. It is also shown from (21) and (22) that even if the expectations, the consumption patterns and the risk aversions are all the same among the home and foreign investors, their risk premiums are not equal to each other. This difference originally stems from the fact that investors usually evaluate their wealth in terms of their domestic money.

The fact that the risk premiums of the home and foreign investors are different each other implies, in turn, that the equilibrium asset prices regarded by them as the international asset market clearing prices are not always equal to each other. In such circumstances, even if the home investor supposes that international asset markets are in equilibrium, the foreign investor 
THE INTERNATIONAL ECONOMY Vol. 46, No. 1, 1995, 3-24

does not think so, and vice versa. Hence, at least one of the home and foreign investors always adjusts his portfolio and the international asset markets including the exchange market tend to be volatile.

In any models where only monies are considered as international assets (say the monies models, hereafter), since investors could not hold any bonds in their portfolios, $b_{h}=b_{h}{ }^{*}=b_{f}=$ $\mathrm{b}_{\mathrm{f}}^{*}=0, \mathrm{~m}_{\mathrm{h}}+\mathrm{m}_{\mathrm{h}}{ }^{*}=1$ and $\mathrm{m}_{\mathrm{f}}+\mathrm{m}_{\mathrm{f}}^{*}=1$ hold. Thus, one can easily get $\partial \mathrm{m}_{\mathrm{h}} / \partial \mathrm{e}=-$ $\partial \mathrm{m}_{\mathrm{h}}{ }^{*} / \partial_{\mathrm{e}}<0, \partial \mathrm{m}_{\mathrm{f}}{ }^{*} / \partial \mathrm{e}=-\partial \mathrm{m}_{\mathrm{f}} / \partial \mathrm{e}>0, \partial \mathrm{m}_{\mathrm{h}} / \partial \sigma_{\mathrm{e}}=-\partial \mathrm{m}_{\mathrm{h}}{ }^{*} / \partial \sigma_{\mathrm{e}}$ and $\partial \mathrm{m}_{\mathrm{f}} / \partial \sigma_{\mathrm{e}}=-\partial \mathrm{m}_{\mathrm{f}}{ }^{*} / \partial \sigma_{\mathrm{e}}$, which implies that in the monies models the home and foreign monies are always perfectly gross substitutive for each other. However, these are contrary to the results in the present model including both monies and bonds. Hence, it is shown that the monies models are very restrictive for analyzing the optimal portfolio rules of international investors and exchange rate determination ${ }^{9}$.

In examining the effects of changes in the foreign investor's expectations of the prices and the exchange rate on his portfolio rule, it is necessary to recall that this paper presumes neither PPP nor the law of one price. If PPP is adopted, the real wealth of the foreign investor is given by $(13)^{\prime}$ and it is the same as that of the home investor given by (5) except that $h$ and $f$ in the subscripts of the parameters are only the difference. And, if the law of one price is assumed, the real wealth of the foreign investor is defined as $(13)^{\prime \prime}$ and it is essentially the same as that of the home investor defined by (5) except that, in addition to $h$ and $f$ in the subscripts of the parameters, investor's consumption expenditure shares $\alpha_{\mathrm{i}}$ and $\beta_{\mathrm{i}}(\mathrm{i}=1,2)$ are different. Therefore, all the signs of the effects of changes in the foreign investor's expectations of the prices and the exchange rate on his portfolio rule are the same as those of the effects of changes in the home investor's expectations of the prices and the exchange rate on his portfolio rule, respectively. These propositions, however, do not hold in this paper which adopts neither PPP nor the law of one price.

\section{Trade Imbalances, Monies, Bonds and the Exchange Rate}

This section first derives the market exchange rate from the equilibrium conditions of international asset markets and then investigates the effects of changes in trade imbalances, monetary and fiscal policies on this rate.

\section{A. International Financial Markets and the Exchange Rate}

Since the financial markets of monies and bonds issued in home and foreign countries are all internationally open and perfectly competitive, individuals in two countries can equally participate in these markets and take the prices observed in these markets as common ones. Moreover, the firms in two countries also take part in the international asset markets.

It is here assumed, without losing the generality, that while the firms hold monies on transaction motives, they do not demand them on speculative motives. It is also supposed, for 
Yasunori Ishii:International Portfolios, Trade Imbalances and the Exchange Rate

simplicity, that the total amount of home money TA (foreign money TAf) held by the firms at

each instant is equal to the instantaneous trade surplus of home country ES (or the instantaneous trade deficit of foreign country-S), where $\mathrm{S}$ is measured in terms of foreign money. This reflects the actual observation that the home firms facing trade surplus paid with foreign money supply them in order to get home money, and vice versa. Thus, the trade surplus of home country results in increases of demand for home money and of supply of foreign money. Then,

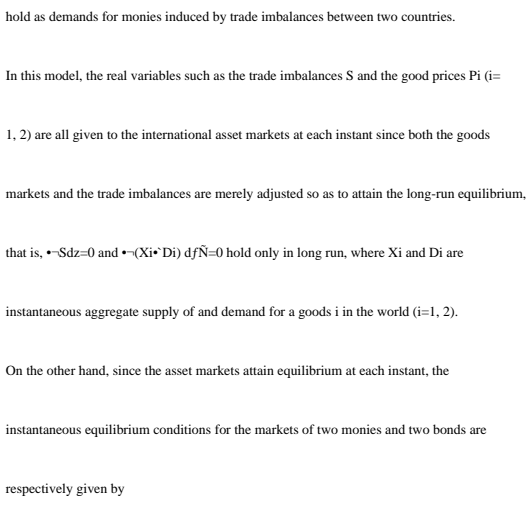

where $\mathrm{Mh}, \mathrm{Mf}^{*}, \mathrm{Bh}, \mathrm{Bf}^{*}, \mathrm{nh}$ and of denote the amounts of monies supplied by the home and foreign monetary authorities, the numbers of bonds issued by the home and foreign governments and the numbers of individuals in the two countries, respectively, and $\mathrm{Mh}, \mathrm{Mf}^{*}, \mathrm{Bh} \mathrm{Bf}^{*}$, nh and nf are al I supPosed to be positive.

The equilibrium condtions of home and foreign money markets, i.e., (24-i) and (24-ii), are expressed by their monies, respectively. It should be also noted that even if some bonds issued by private sectors are included in bond holdings of investors, they do not appear in the equilibrium conditions (24-iii) and (24-iv) of the international bond markets since these private bonds cancel out each other among themselves in equilibrium. Furthermore, Mh, Mf*, $\mathrm{Bh}, \mathrm{Bf}^{*}$, nh and $\mathrm{nf}$ are all regarded as parameters since the former four are political variables of the home and foreign governments, and the latter two are noneconomic ones which are not determined in the asset markets. Substituting $\mathrm{mh}=\mathrm{QMh} / \mathrm{W}, \mathrm{bh}=\mathrm{QPb} \mathrm{Bh} / \mathrm{W}, \mathrm{mh}^{*}=\mathrm{QEMh} * / \mathrm{W}, \mathrm{bh}^{*}=\mathrm{QEPb} * \mathrm{Bh} * / \mathrm{W}, \mathrm{mf}=\mathrm{Q} *$ $\mathrm{EMf} / \mathrm{Wf}, \mathrm{bf}=\mathrm{Q} * \mathrm{EPbBf} / \mathrm{Wf}, \mathrm{mf}^{*}=\mathrm{Q}^{*} \mathrm{Mf} f^{*} / \mathrm{Wf}, \mathrm{bf}^{*}=\mathrm{Q}^{*} \mathrm{~Pb} * \mathrm{Bf}^{*} / \mathrm{Wf}(15)$ and (23) into (24), and arranging the results, the equilibrium conditions (24) of the international asset markets are rewritten as 
(i) $M_{h}=m_{h} W_{M}+m_{f} \mathrm{EW}_{\mathrm{Mf}}+\mathrm{ES}$,

(ii) $\mathrm{EM}_{f}^{*}=\mathrm{m}_{\mathrm{h}} * \mathrm{~W}_{\mathrm{M}}+\mathrm{m}_{\mathrm{f}}^{*} \mathrm{EW}_{\mathrm{Mf}}-\mathrm{ES}$,

(iii) $\mathrm{P}_{\mathrm{b}} B_{h}=\mathrm{b}_{\mathrm{h}} \mathrm{W}_{\mathrm{M}}+\mathrm{b}_{\mathrm{f}} \mathrm{EW}_{\mathrm{Mf}}$,

(iv) $\mathrm{EP}_{\mathrm{b}} * B_{f}^{*}=\mathrm{b}_{\mathrm{h}} * \mathrm{~W}_{\mathrm{M}}+\mathrm{b}_{\mathrm{f}} * \mathrm{EW}_{\mathrm{Mf}}$,

where $\mathrm{W}_{\mathrm{M}}=\mathrm{n}_{\mathrm{h}}\left\{\left(\mathrm{M}_{\mathrm{h}}+\mathrm{P}_{\mathrm{b}} \mathrm{B}_{\mathrm{h}}\right)+\mathrm{E}\left(\mathrm{M}_{\mathrm{h}}{ }^{*}+\mathrm{P}_{\mathrm{b}}{ }^{*} \mathrm{~B}_{\mathrm{h}}{ }^{*}\right)\right\}=\mathrm{n}_{\mathrm{h}} \mathrm{W} / \mathrm{Q}$ and $\mathrm{W}_{\mathrm{Mf}}=\mathrm{n}_{\mathrm{f}}\left\{\left(\mathrm{M}_{\mathrm{f}}+\right.\right.$ $\left.\left.\mathrm{P}_{\mathrm{b}} \mathrm{B}_{\mathrm{f}}\right) \tilde{\mathrm{E}}+\left(\mathrm{M}_{\mathrm{f}} *+\mathrm{P}_{\mathrm{b}} * \mathrm{~B}_{\mathrm{f}}^{*}\right)\right\}=\mathrm{n}_{\mathrm{f}} \mathrm{W}_{\mathrm{f}} / \mathrm{Q}^{*}$ are the total wealth held by individuals of the home and foreign countries, respectively. Therefore, $(24)^{\prime}$ indicates that the equilibrium asset prices depend on the goods prices, the investors' portfolio rules in two countries, the aggregate nominal wealth of individuals in two countries, the total amounts of monies and government bonds supplied by two countries and the trade imbalances between two countries.

Since $m_{h}+m_{h}{ }^{*}+b_{h}+b_{h}{ }^{*}=1, m_{f}+m_{f}{ }^{*}+b_{f}+b_{f}{ }^{*}=1$ and (24)' combine to give $M_{h}$ $+\mathrm{EM}_{f}^{*}+\mathrm{P}_{\mathrm{b}} B_{h}+\mathrm{EP}_{\mathrm{b}}{ }^{*} B_{f}^{*}=\mathrm{W}_{\mathrm{M}}+\mathrm{EW}_{\mathrm{Mf}}$ as the world financial budget constraint, it is clear that though (24)' consists of four equations including the good prices, the bond prices and the exchange rate as its variables, any three equations of (24)' solve the exchange rate $\mathrm{E}$ and the two bond prices $\mathrm{P}_{b}$ and $\mathrm{P}_{b}$ * which attain the asset market equilibrium if the trade imbalance $\mathrm{S}$ and the goods prices $\mathrm{P}_{\mathrm{i}}$ and $\mathrm{P}_{\mathrm{i}}^{*}(\mathrm{i}=1,2)$ are determined in the real markets. Thus, considering (8), (15) and $(24)^{\prime}$, the bond prices $\mathrm{P}_{\mathrm{b}}$ and $\mathrm{P}_{\mathrm{b}}{ }^{*}$ and the exchange rate $\mathrm{E}$ at the equilibrium of international asset markets are given by

(i ) $\mathrm{P}_{\mathrm{b}}=\mathrm{P}_{\mathrm{b}}\left(\alpha_{1}, \beta_{1}, \mathrm{p}_{\mathrm{g}}, \mathrm{p}_{\mathrm{gf}}, \mathrm{p}_{\mathrm{b}}, \mathrm{p}_{\mathrm{b}}{ }^{*}, \mathrm{e}, \mathrm{p}_{\mathrm{bf}}, \mathrm{p}_{\mathrm{b}}{ }_{\mathrm{f}}, \mathrm{e}_{\mathrm{f}}, \sigma_{\mathrm{ij}}, \sigma_{\mathrm{ijf}}, \mathrm{P}_{\mathrm{g}}, \mathrm{P}_{\mathrm{g}}{ }^{*}\right.$,

$$
\left.\mathrm{T}_{\mathrm{R}}, \mathrm{T}_{\mathrm{Rf}}, M_{h}, M_{f}^{*}, B_{h}, B_{f}^{*}, \mathrm{~S}, \mathrm{n}, \mathrm{n}_{\mathrm{f}}\right),
$$

(ii) $\mathrm{P}_{\mathrm{b}}{ }^{*}=\mathrm{P}_{\mathrm{b}}{ }^{*}\left(\alpha_{1}, \beta_{1}, \mathrm{p}_{\mathrm{g}}, \mathrm{p}_{\mathrm{gf}}, \mathrm{pb}, \mathrm{p}_{\mathrm{b}}{ }^{*}, \mathrm{e}, \mathrm{p}_{\mathrm{bf}}, \mathrm{p}_{\mathrm{b}}{ }_{\mathrm{f}}, \mathrm{e}_{\mathrm{f}}, \sigma_{\mathrm{ij}}, \sigma_{\mathrm{ijf}}, \mathrm{P}_{\mathrm{g}}\right.$,

$$
\left.\mathrm{P}_{\mathrm{g}}^{*}, \mathrm{~T}_{\mathrm{R}}, \mathrm{T}_{\mathrm{Rf}}, M_{h}, M_{f}^{*}, B_{h}, B_{f}^{*}, \mathrm{~S}, \mathrm{n}, \mathrm{n}_{\mathrm{f}}\right),
$$

(iii) $\mathrm{E}=\mathrm{E}\left(\alpha_{1}, \beta_{1}, \mathrm{pg}, \mathrm{pgf}_{\mathrm{gf}}, \mathrm{pb}, \mathrm{p}^{*}, \mathrm{e}, \mathrm{pbf}_{\mathrm{bf}} \mathrm{p}^{*}{ }_{\mathrm{f}}, \mathrm{e}_{\mathrm{f}}, \sigma_{\mathrm{ij}}, \sigma_{\mathrm{ijf}}, \mathrm{Pg}_{\mathrm{g}}, \mathrm{P}_{\mathrm{g}}^{*}\right.$,

$$
\begin{aligned}
& \left.\mathrm{T}_{\mathrm{R}}, \mathrm{T}_{\mathrm{Rf}}, M_{h}, M_{f}^{*}, B_{h}, B_{f}^{*}, \mathrm{~S}, \mathrm{n}, \mathrm{n}_{\mathrm{f}}\right), \\
& \left(\mathrm{g}=1,2 \text { and } \mathrm{i}, \mathrm{j}=1,2, \mathrm{~b}, \mathrm{~b}^{*}, \mathrm{e}\right) .
\end{aligned}
$$

It is shown from (25) that the exchange rate and the bond prices are the functions of all individual' consumption patterns, their expectations of the asset and goods prices, their degrees of risk tolerance, the goods prices, the amounts of monies and government bonds supplied in two countries, the amount of trade imbalances, and the number of individuals in two countries.

The feature that the exchange rate function includes the goods prices and the trade imbalances as its arguments among others stems from the dual equilibrium hypothesis adopted in this model. Indeed, if the international asset markets, the goods markets and the trade balances attain the simultaneous equilibrium, all the asset prices, the goods prices and the trade balances are determined simultaneously. Thus, adopting the usual equilibrium hypothesis which assumes the simultaneous equilibrium of the international asset markets, the goods markets and the trade balances, one cannot assert that the exchange rate depends on the levels of goods prices and the amount of trade imbalances. 
Yasunori Ishii : International Portfolios, Trade Imbalances and the Exchange Rate

\section{B. Trade Surplus, Monetary and Fiscal Policies and the Exchange Rate}

I here examine the effects of the amounts of monies and bonds issued by the home and foreign governments and the trade imbalances on the exchange rate. So, for simplicity, it is additionally assumed that all the investors' expectations of the goods prices and the asset prices follow the "geometric Brownian motion" which has often been adopted in many papers. In such a case the wealth is an only state variable and thus all $\mathrm{\Psi}_{\mathrm{WK}}\left(\mathrm{K}=\mathrm{P}_{\mathrm{i}}, \mathrm{P}_{\mathrm{b}}, \mathrm{P}_{\mathrm{b}}\right.$, $\left.\mathrm{E}\right)$ become zero.

Before proceeding to the derivation of the exchange rate, I consider an interesting financial feature of the local asset preferences in the sence that the home(foreign) investors hold larger proportions of home(foreign) assets in their wealth than the foreign(home) investors do, respectively. This feature is taken as very plausible since the home(foreign) investors have tendencies to suppose that home(foreign) assets are much safer than foreign(home) assets. In this paper with four assets, the local asset preference implies $m_{h}>m_{f}, m_{f}{ }^{*}>m_{h}{ }^{*}, b_{h}>b_{f}$ and $b_{f}^{*}>b_{h} *$. Then, one easily obtains

$$
\left(m_{h}{ }^{*} b_{f}-m_{f}^{*} b_{h}\right)<0, \quad \text { and }\left(m_{f}^{*} m_{h}-m_{h}{ }^{*} m_{f}\right)>0 .
$$

In the following, I shall adopt (26) in analyzing the effects of large and marginal changes in the trade imbalances, the monetary and fiscal policies of two countries on the exchange rate and so on. Moreover, it is also supposed that the home country faces trade surplus like Japan.

\section{B.I Large Changes in Amounts of Trade Imbalances and Monies}

Solving $\mathrm{W}_{\mathrm{M}}$ and $\mathrm{W}_{\mathrm{Mf}}$ from (24. i $)^{\prime}$ and (24. ii )' and taking account of $0<\mathrm{W}_{\mathrm{M}}, 0<\mathrm{W}_{\mathrm{Mf}}$ and (26), one gets

$$
\rho<\mathrm{E}<\delta
$$

where

$$
\begin{aligned}
& \rho=\mathrm{m}_{\mathrm{h}}{ }^{*} M_{\mathrm{h}} /\left\{\mathrm{m}_{\mathrm{h}} M_{f}^{*}+\left(\mathrm{m}_{\mathrm{h}}+\mathrm{m}_{\mathrm{h}}{ }^{*}\right) \mathrm{S}\right\}, \\
& \delta=\mathrm{m}_{\mathrm{f}}^{*} M_{h} /\left\{\mathrm{m}_{\mathrm{f}} M_{f}^{*}+\left(\mathrm{m}_{\mathrm{f}}+\mathrm{m}_{\mathrm{f}}{ }^{*}\right) \mathrm{S}\right\} .
\end{aligned}
$$

Obviously, the exchange rate is generally bounded both from the above and from the below, and both these limits increase as the supply of home money rises and as the supply of foreign money and/or the trade surplus of the home country decrease, and vice versa. Hence, while a considerably large increase(decrease) in the trade surplus of home country leads to the appreciation(depreciation) of home money, a considerably huge increase in the supply of home (foreign) money results in the depreciation(appreciation) of home money, and vice versa.

In this context, a considerably large change in trade imbalance and/or money supply implies that it is large enough to make the upper(lower) limit of the exchange rate lower(higher) than the current level. In practice it would be shown that the Japanese trade surplus in the recent years has been large enough to make the upper limit, $\delta$, lower than the current exchange rate $\mathrm{E}$ (the price of a dollar in terms of yen), and yen has been appreciating against dollar as its trend. Thus, it is proposed that any market interventions by the Japanese and/or U.S. monetary authorities aiming to control the drastic appreciation of yen must be large enough to stop the 
shift of this upper limit or to return such a shift to the opposite direction.

\section{B.II Marginal Changes in Amounts of Trade Imbalance, Monies and Bonds}

In order to analyze the effects of marginal changes in the amounts of trade imbalances, monies and bonds controlled by the home and foreign governments on the exchange rate, I derive the equation which expresses a relationship among the exchange rate, the trade imbalances and the amounts of monies and bonds supplied by two countries. From $(24-\mathrm{i})^{\prime},(24-\mathrm{ii})^{\prime}$ and $(24-\mathrm{iii})^{\prime}$ we obtain

$$
\mathrm{E}=\frac{\left(\mathrm{m}_{\mathrm{h}}{ }^{*} \mathrm{~b}_{\mathrm{f}}-\mathrm{m}_{\mathrm{f}}^{*} \mathrm{~b}_{\mathrm{h}}\right) M_{\mathrm{h}}+\left(\mathrm{m}_{\mathrm{f}}^{*} \mathrm{~m}_{\mathrm{h}}-\mathrm{m}_{\mathrm{f}} \mathrm{m}_{\mathrm{h}}^{*}\right) \mathrm{P}_{\mathrm{b}} B_{\mathrm{h}}}{\left(\mathrm{m}_{\mathrm{h}} \mathrm{b}_{\mathrm{f}}-\mathrm{b}_{\mathrm{h}} \mathrm{m}_{\mathrm{f}}\right) M_{\mathrm{f}}^{*}+\left(\mathrm{m}_{\mathrm{h}} \mathrm{b}_{\mathrm{f}}-\mathrm{b}_{\mathrm{h}} \mathrm{m}_{\mathrm{f}}+\mathrm{m}_{\mathrm{h}} \mathrm{b}_{\mathrm{f}}-\mathrm{m}_{\mathrm{f}}^{*} \mathrm{~b}_{\mathrm{h}}\right) \mathrm{S}} .
$$

This demonstrates that the exchange rate depends on the portfolio rules of individuals in two countries, the amounts of monies and bonds supplied by two countries and the trade imbalances between two countries. If the trade account is balanced at each instant, then the exchange rate E does not depend on $\mathrm{S}$.

As a monetary policy engaged by the monetary authorities let us consider the open market operation. In this case any increase(decrease) in the amount of home money operated by the home monetary authorities is accompanied by the same volume of decrease(increase) in the amount of home bonds, and thus one has $\partial \mathrm{P}_{\mathrm{b}} B_{h} / \partial \mathrm{M}_{h}=-1$. Hence, the effect of a change in the amount of home money controlled by the home monetary authorities on the exchange rate is given by

$$
\frac{\partial \mathrm{E}}{\partial M_{h}}=\frac{\left(\mathrm{m}_{\mathrm{h}}^{*} \mathrm{~b}_{\mathrm{f}}-\mathrm{m}_{\mathrm{f}}^{*} \mathrm{~b}_{\mathrm{h}}\right)-\left(\mathrm{m}_{\mathrm{f}}^{*} \mathrm{~m}_{\mathrm{h}}-\mathrm{m}_{\mathrm{f}} \mathrm{m}_{\mathrm{h}}^{*}\right)}{\left(\mathrm{m}_{\mathrm{h}} \mathrm{b}_{\mathrm{f}}-\mathrm{b}_{\mathrm{h}} \mathrm{m}_{\mathrm{f}}\right) M_{f}^{*}+\left(\mathrm{m}_{\mathrm{h}} \mathrm{b}_{\mathrm{f}}-\mathrm{b}_{\mathrm{h}} \mathrm{m}_{\mathrm{f}}+\mathrm{m}_{\mathrm{h}}{ }^{*} \mathrm{~b}_{\mathrm{f}}-\mathrm{m}_{\mathrm{f}}{ }^{*} \mathrm{~b}_{\mathrm{h}}\right) \mathrm{S}} .
$$

Since $\left(m_{h}{ }^{*} b_{f}-m_{f}{ }^{*} b_{h}\right)$ and $\left(m_{f} * m_{h}-m_{f} m_{h}{ }^{*}\right)$ are negative and positive from (26) respectively, the right side of (29) is positive if $\left(m_{h} b_{f}-b_{h} m_{f}\right)$ is negative. But, if $\left(m_{h} b_{f}-b_{h} m_{f}\right)$ is positive, the sign of (29) is ambiguous.

From (24) one gets $\operatorname{sign}\left(\mathrm{m}_{\mathrm{h}} \mathrm{b}_{\mathrm{f}}-\mathrm{b}_{\mathrm{h}} \mathrm{m}_{\mathrm{f}}\right)=\operatorname{sign}\left(\mathrm{b}_{\mathrm{f}} / \mathrm{b}_{\mathrm{h}}-\mathrm{m}_{\mathrm{f}} / \mathrm{m}_{\mathrm{h}}\right)=\operatorname{sign}\left\{B_{h} / \mathrm{n}_{\mathrm{h}} \mathrm{B}_{\mathrm{h}}-\left(M_{h}-\right.\right.$ $\left.\left.T_{A}\right) / n_{h} M_{h}\right\}$. It follows that $\left(m_{h} b_{f}-b_{h} m_{f}\right)$ is negative(positive) when the ratio between quantities of bonds demanded and supplied in home country, $B_{h} / \mathrm{n}_{\mathrm{h}} \mathrm{B}_{\mathrm{h}}$, is larger(smaller) than the ratio between net values of home money held and issued in home country, $\left(M_{h}-\mathrm{T}_{\mathrm{A}}\right) / \mathrm{n}_{\mathrm{h}} \mathrm{M}_{\mathrm{h}}$. In what follows, when $\mathrm{n}_{\mathrm{h}} \mathrm{B}_{\mathrm{h}} / B_{h}>(<) \mathrm{n}_{\mathrm{h}} \mathrm{M}_{\mathrm{h}} /\left(M_{h}-\mathrm{T}_{\mathrm{A}}\right)$ holds, I call the home country a relatively bond(money) preferring country. Then, one can propose :

$$
\left(m_{h} b_{f}-b_{h} m_{f}\right)<(>) 0 \text { as the home country is a relatively }
$$

$$
\text { bond(money) preferring country. }
$$

In practice, whether the home country is a relatively bond preferring country or a relatively money preferring country depends only on the portfolio rules of individuals in the home country.

Now, considering (29) and (30), it is shown that if the home country is a relatively bond preferring country a marginal expanding open market operation by the home monetary authorities depreciates home money against foreign money, and vice versa. However, if the home country is 
Yasunori Ishii : International Portfolios, Trade Imbalances and the Exchange Rate

a relatively money preferring country the sign of (29) is ambiguous.

On the other hand, in the case where the international trades of assets are sufficiently small, that is, $\mathrm{m}_{\mathrm{h}}{ }^{*} \fallingdotseq 0, \mathrm{~b}_{\mathrm{h}}{ }^{*} \fallingdotseq 0, \mathrm{~m}_{\mathrm{f}} \fallingdotseq 0$ and $\mathrm{b}_{\mathrm{f}} \fallingdotseq 0$ hold, (29) is rewritten as

$$
\frac{\partial \mathrm{E}}{\partial M_{h}} \fallingdotseq \frac{\mathrm{b}_{\mathrm{h}}+\mathrm{m}_{\mathrm{h}}}{\mathrm{b}_{\mathrm{h}} \mathrm{S}}>0
$$

It follows that if the international assets trades are sufficiently small the marginal expanding open market operation by the home monetary authorities always raises the exchange rate E, and vice versa.

Now (29) and (31) combine to show that as international trades of assets become significant, there emerges a possibility that the effect of a marginal change in open market operation by the home monetary authorities on the exchange rate is negative. Thus, in such circumstances the co-existence of the appreciation(depreciation) and the expansion(reduction) of home money through the open market operation is observed ${ }^{10}$.

The effect of a change in the amount of foreign money $M_{f}^{*}$ supplied by the foreign monetary authorities on the exchange rate $\mathrm{E}$ is given by

$$
\frac{\partial \mathrm{E}}{\partial M_{f}^{*}}=\frac{\left(\mathrm{m}_{\mathrm{f}}^{*} \mathrm{~m}_{\mathrm{h}}-\mathrm{m}_{\mathrm{f}} \mathrm{m}_{\mathrm{h}}^{*}\right) \partial \mathrm{P}_{\mathrm{b}} B_{h} / \partial M_{f}^{*}-\mathrm{E}\left(\mathrm{m}_{\mathrm{h}} \mathrm{b}_{\mathrm{f}}-\mathrm{b}_{\mathrm{h}} \mathrm{m}_{\mathrm{f}}\right)}{\left(\mathrm{m}_{\mathrm{h}} \mathrm{b}_{\mathrm{f}}-\mathrm{b}_{\mathrm{h}} \mathrm{m}_{\mathrm{f}}\right) M_{f}^{*}+\left(\mathrm{m}_{\mathrm{h}} \mathrm{b}_{\mathrm{f}}-\mathrm{b}_{\mathrm{h}} \mathrm{m}_{\mathrm{f}}+\mathrm{m}_{\mathrm{h}}{ }^{*} \mathrm{~b}_{\mathrm{f}}-\mathrm{m}_{\mathrm{f}} \mathrm{b}_{\mathrm{h}}\right) \mathrm{S}}
$$

Clearly $\left(\partial \mathrm{Pb} / \partial M_{f}^{*}\right)$ is positive since an increase(a decrease) in $M_{f}^{*}$ increases(decreases) demands for home bonds and, thus, raises(declines) the home bond price. Thus (26), (30) and (32) show that, if the home country is a relatively bond preferring country, a marginal increase in the amount of money supplied by the foreign monetary authorities appreciates home money against foreign money and vice versa. However, if the home country is a relatively money preferring country, the effect of a marginal change in the supply of foreign money on the exchange rate is ambiguous and there is a possibility that the exchange rate and the supply of foreign money move in the same directions.

When the international asset trades are sufficiently small, (32) reduces to

$$
\frac{\partial \mathrm{E}}{\partial M_{f}^{*}} \fallingdotseq \frac{\mathrm{m}_{\mathrm{f}}^{*} \mathrm{~m}_{\mathrm{h}} \partial \mathrm{P}_{\mathrm{b}} B_{h} / \partial M_{f}^{*}}{\left(\mathrm{~m}_{\mathrm{h}}^{*} \mathrm{~b}_{\mathrm{f}}-\mathrm{m}_{\mathrm{f}}^{*} \mathrm{~b}_{\mathrm{h}}\right) \mathrm{S}} .
$$

Then, since $\partial \mathrm{P}_{\mathrm{b}} B_{h} / \partial M_{f}^{*}>0$ and $\left(\mathrm{m}_{\mathrm{h}}{ }^{*} \mathrm{~b}_{\mathrm{f}}-\mathrm{m}_{\mathrm{f}}{ }^{*} \mathrm{~b}_{\mathrm{h}}\right) \mathrm{S}>0$ hold for the home country from the above arguments and (26), the right side of (33) is always negative. Therefore, if the international asset trades are sufficiently small a marginal increase in the foreign money supply always appreciates home money against foreign money, and vice versa.

As a fiscal policy, consider a pure bond policy that a change in the amount of home government bonds by the fiscal authorities is not accompanied by any change in the supply of home money by the monetary authorities. This kind of bond policy is often observed in such the case where the fiscal authorities independently vary the existing amount of bonds in order to pursue its own political purpose without any cooperation of the monetary authorities. In this 
case, since $\partial \mathrm{M}_{\mathrm{h}} / \partial\left(\mathrm{P}_{\mathrm{b}} B_{h}\right)=0$ holds, the effect of a change in the amount of government bonds on the exchange rate is given by

$$
\frac{\partial \mathrm{E}}{\partial \mathrm{P}_{\mathrm{b}} B_{h}}=\frac{\left(\mathrm{m}_{\mathrm{f}}{ }^{*} \mathrm{~m}_{\mathrm{h}}-\mathrm{m}_{\mathrm{f}} \mathrm{m}_{\mathrm{h}}{ }^{*}\right)}{\left(\mathrm{m}_{\mathrm{h}} \mathrm{b}_{\mathrm{f}}-\mathrm{b}_{\mathrm{h}} \mathrm{m}_{\mathrm{f}}\right) M_{f}^{*}+\left(\mathrm{m}_{\mathrm{h}} \mathrm{b}_{\mathrm{f}}-\mathrm{b}_{\mathrm{h}} \mathrm{m}_{\mathrm{f}}+\mathrm{m}_{\mathrm{h}}{ }^{*} \mathrm{~b}_{\mathrm{f}}-\mathrm{m}_{\mathrm{f}}{ }^{*} \mathrm{~b}_{\mathrm{h}}\right) \mathrm{S}} .
$$

From (26), (30) and (34) it is demonstrated that if the home country is a relatively bond preferring country, a marginal increase in the volume of home bonds issued by the home government appreciates home money, and vice versa. On the other hand, the sign of this effect is ambiguous in a case where the home country is a relatively money preferring country and there is a possibility that a marginal increase (decrease) in the volume of home bonds issued by the home government depreciates (appreciates) home money ${ }^{11}$.

If the international trades of assets are sufficiently small, the effect of a change in the amount of government bonds on the exchange rate is given by

$$
\partial \mathrm{E} / \partial \mathrm{P}_{\mathrm{b}} B_{h} \fallingdotseq 0 \text {. }
$$

Hence, in circumstances where the international asset trades are sufficiently small the exchange rate is independent of a marginal change in the volume of the bonds issued by the home government and does not depend on whether the home country is a relatively bond preferring country or a relatively money preferring country.

Finally, the effect of a marginal change in trade surplus of the home country on the exchange rate is given by

$$
\frac{\partial \mathrm{E}}{\partial \mathrm{S}}=\frac{\left(\mathrm{m}_{\mathrm{f}}^{*} \mathrm{~m}_{\mathrm{h}}-\mathrm{m}_{\mathrm{f}} \mathrm{m}_{\mathrm{h}}{ }^{*}\right) \partial \mathrm{P}_{\mathrm{b}} B_{\mathrm{h}} / \partial \mathrm{S}-\mathrm{E}\left(\mathrm{m}_{\mathrm{h}} \mathrm{b}_{\mathrm{f}}-\mathrm{b}_{\mathrm{h}} \mathrm{m}_{\mathrm{f}}+\mathrm{m}_{\mathrm{h}}{ }^{*} \mathrm{~b}_{\mathrm{f}}-\mathrm{m}_{\mathrm{f}}^{*} \mathrm{~b}_{\mathrm{h}}\right.}{\left(\mathrm{m}_{\mathrm{h}} \mathrm{b}_{\mathrm{f}}-\mathrm{b}_{\mathrm{h}} \mathrm{m}_{\mathrm{f}}\right) M_{f}{ }^{*}+\left(\mathrm{m}_{\mathrm{h}} \mathrm{b}_{\mathrm{f}}-\mathrm{b}_{\mathrm{h}} \mathrm{m}_{\mathrm{f}}+\mathrm{m}_{\mathrm{h}}{ }^{*} \mathrm{~b}_{\mathrm{f}}-\mathrm{m}_{\mathrm{f}}{ }^{*} \mathrm{~b}_{\mathrm{h}}\right) \mathrm{S}} .
$$

Considering that $\partial \mathrm{P}_{\mathrm{b}} / \partial \mathrm{S}$ is regarded as positive since an increase(a decrease) in $\mathrm{S}$ increases (decreases) demands for home bonds and raises(declines) the home bond price, (26) and (30) ensure that the right side of $(36)$ is negative in a case of $\left(m_{h} b_{f}-b_{h} m_{f}\right)<0$. Consequently, a marginal increase(decrease) in trade surplus of the home country appreciates(depreciates) home money when the home country is a relatively bond preferring country. On the contrary, when the home country is a relatively money preferring country the effect of a marginal change in trade surplus of the home country on the exchange rate is ambiguous, and thus there is a possibility that a marginal increase(decrease) in trade surplus of the home country depreciates(appreciates) home money against foreign money.

If the international trades of assets are sufficiently small, (36) becomes

$$
\partial \mathrm{E} / \partial \mathrm{S} \fallingdotseq-\left(\mathrm{m}_{\mathrm{h}} \partial \mathrm{P}_{\mathrm{b}} B_{h} / \partial \mathrm{S}+\mathrm{Eb}_{\mathrm{h}}\right) / \mathrm{b}_{\mathrm{h}} \mathrm{S} \text {, }
$$

which implies that a marginal increase(decrease) in trade surplus of the home country always appreciates(depreciates) home money against foreign money when the international asset trades are sufficiently small. The propositions with respect to (36) and (37) also combine to show that as the international asset trades become significant, we have a possibility that the effect of a marginal increase(decrease) in trade surplus of the home country on the exchange rate becomes 
Yasunori Ishii : International Portfolios, Trade Imbalances and the Exchange Rate

positive(negative).

\section{Concluding Remarks}

This paper firstly establishes a generalized two-country, two-good, two-money, two-bond continuous-time international portfolio model considering the uncertainty with respect to the exchange rate, the goods prices and the bond prices in order to examine the portfolio rules of international investors. Then the equilibrium conditions of international asset markets are proposed to analyze the exchange rate determination and the effects of changes in trade imbalances, monetary and fiscal policies on the exchange rate. This paper does not assume purchasing power parity(PPP), interest rate parity(IRP), the law of one price and the investors' homogeneous expectations and the one-kind-asset world with only either monies or bonds.

Since the PPP assumption implicitly requires the same consumption patterns of individuals in two countries and the law of one price, PPP does not hold in general. IRP does not generally hold either since both the expectations and attitudes toward risk of home investors are not the same as those of foreign investors. It is well known that uncertainty of $E$ is not equal to that of $1 / \mathrm{E}$. One of the significant features of a monetary economy is that international investors usually evaluate their own wealth in terms of their domestic monies.

In discussing the individuals' international portfolio rules this paper considers four kinds of assets, that is, monies and bonds supplied in the two countries. Therefore, it can investigate more actually some of interesting phenomena observed in the international asset markets. It describes the international portfolio rules including these four assets and proves that home and foreign monies as well as home and foreign bonds are not perfectly gross substitutive for each other. This implies, in turn, that the propositions on the assumption of homogeneous investors do not hold in general.

The general equilibrium analysis of international asset markets shows that the exchange rate depends on the consumption and portfolio rules of investors in two countries which, in turn, depend on their expectations and their attitudes toward risk, the amounts of monies and bonds issued in two countries and the volume of trade imbalances between two countries, among others. In particular, the main result that the exchange rate depends on the volume of trade imbalances between two countries stems from the fact that the adjustment speed of asset markets is much faster than that of trade imbalances.

Finally the paper examines the effects of changes in the amount of monies and bonds controlled by the home and foreign governments and the volume of trade imbalances between two countries on the exchange rate. It is shown that the signs of large changes in these parameters on the exchange rate are always judged definitely and that the signs of marginal changes in these parameters on the exchange rate are also determined in the case where the volumes of international asset trades are sufficiently small. 
However, it is proposed that as the volume of international asset trades becomes significant the signs of marginal changes in these parameters on the exchange rate are ambiguous without the condition that the home country is a bond preferring country. Therefore, if this condition is not satisfied there is a possibility that a marginal expansion(reduction) of home money through open market operation and/or a marginal decrease(increase) in trade surplus of the home country appreciates(depreciates) home money against foreign money.

The model in this paper could be further extended in some directions. The explicit introduction of real sectors will make clearer long-run relationships between financial and real sectors. And the model will also be extended so as to investigate some welfare aspects of international financial markets.

\section{Appendix}

To solve the continuous-time consumption-portfolio problem of the home investor, the technique of stochastic dynamic programming is used. Define

$$
\mathrm{J}\left(\mathrm{W}, \mathrm{P}_{1}, \mathrm{P}_{2}, \mathrm{P}_{\mathrm{b}}, \mathrm{P}_{\mathrm{b}} *, E\right) \equiv \max \cdot E_{\mathrm{t}}\left[\int_{\mathrm{t}}^{\mathrm{T}} \widetilde{\mathrm{u}}(\tau) \mathrm{d} \tau\right]
$$

where $E_{t}$ is the conditional expectation operator, conditional on $W(t)=W, P_{1}(t)=P_{1}, P_{2}(t)=$ $\mathrm{P}_{2}, \mathrm{P}_{\mathrm{b}}(\mathrm{t})=\mathrm{P}_{\mathrm{b}}, \mathrm{P}_{\mathrm{b}} *(\mathrm{t})=\mathrm{P}_{\mathrm{b}}{ }^{*}$ and $\mathrm{E}(\mathrm{t})=\mathrm{E}$. Since $\tilde{\mathrm{u}}$ is strictly concave in $\mathrm{x}_{\mathrm{i}}$, there exist, by Bellman's theorem, optimal controls, $\mathrm{x}_{\mathrm{i}}, \mathrm{m}_{\mathrm{h}}, \mathrm{b}_{\mathrm{h}}, \mathrm{m}_{\mathrm{h}}{ }^{*}$ and $\mathrm{b}_{\mathrm{h}}{ }^{*}$ which maximize $\mathrm{F}$ defined such as

$$
\mathrm{F}\left(\mathrm{x}_{1}, \mathrm{x}_{2}, \mathrm{~m}_{\mathrm{h}}, \mathrm{b}_{\mathrm{h}}, \mathrm{m}_{\mathrm{h}}{ }^{*}, \mathrm{~b}_{\mathrm{h}}{ }^{*}, \mathrm{~W}, \mathrm{P}_{1}, \mathrm{P}_{2}, \mathrm{P}_{\mathrm{b}}, \mathrm{P}_{\mathrm{b}}{ }^{*}, \mathrm{E}\right)=\widetilde{\mathrm{u}}+\Theta(\mathrm{J}),
$$

where $\Theta(\mathrm{J})$ denotes the Dynkin operator.

Denoting as subscripts the partial derivatives of the Bellman function $J$ with respect to its arguments, and considering $m_{h}+b_{h}+m_{h}{ }^{*}+b_{h}{ }^{*}=1,(1)$ and (A.1), one obtains its average expected change per unit of time as

$$
\begin{aligned}
\Theta(\mathrm{J})= & \mathrm{J}_{\mathrm{W}}\left[\left(\mathrm{Ab}_{\mathrm{h}}+\mathrm{Bm}_{\mathrm{h}}{ }^{*}+\mathrm{Cb}_{\mathrm{h}}{ }^{*}+\mathrm{D}\right) \mathrm{W}-\mathrm{X}_{\mathrm{C}}\right]+\sum_{\mathrm{i}} \mathrm{J}_{\mathrm{Pi}} \mathrm{p}_{\mathrm{i}} \mathrm{P}_{\mathrm{i}}+\mathrm{J}_{\mathrm{Pb}} \mathrm{pb}_{\mathrm{b}} \mathrm{P}_{\mathrm{b}} \\
& +\mathrm{J}_{\mathrm{Pb}}{ } \mathrm{p}_{\mathrm{b}}{ }^{*} \mathrm{P}_{\mathrm{b}}{ }^{*}+\mathrm{J}_{\mathrm{E}} \mathrm{eE}+1 / 2 \mathrm{~J}_{\mathrm{Ww}}\left[\left\{\alpha_{1} \sigma_{1}+\alpha_{2} \sigma_{2}+\sigma_{\mathrm{b}} \mathrm{b}_{\mathrm{h}}+\sigma_{\mathrm{b}}{ }^{*} \mathrm{~b}_{\mathrm{h}}{ }^{*}\right.\right. \\
& \left.\left.+\sigma_{\mathrm{e}}\left(\mathrm{m}_{\mathrm{h}}{ }^{*}+\mathrm{b}_{\mathrm{h}}{ }^{*}\right)\right\}^{2} \mathrm{~W}^{2}\right]+\sum_{\mathrm{K}} \mathrm{J}_{\mathrm{WK}}\left[\left\{-\alpha_{1} \sigma_{1 \mathrm{k}}-\alpha_{2} \sigma_{2 \mathrm{k}}+\sigma_{\mathrm{bk}} \mathrm{b}_{\mathrm{h}}+\sigma_{\mathrm{b}}{ }_{\mathrm{k}} \mathrm{b}_{\mathrm{h}}{ }^{*}\right.\right. \\
& \left.\left.+\sigma_{\mathrm{ek}}\left(\mathrm{m}_{\mathrm{h}}{ }^{*}+\mathrm{b}_{\mathrm{h}}{ }^{*}\right)\right\} \mathrm{WK}\right]+1 / 2 \sum_{\mathrm{H}} \sum_{\mathrm{K}} \mathrm{J}_{\mathrm{HK}} \sigma_{\mathrm{Hk}} \mathrm{HK},
\end{aligned}
$$

where $\mathrm{i}=1,2$, and $\mathrm{K}$ (and $\mathrm{H})=\mathrm{P}_{1}, \mathrm{P}_{2}, \mathrm{P}_{\mathrm{b}}, \mathrm{P}_{\mathrm{b}}{ }^{*}, \mathrm{E}$ are used, for notational simplicity. Hence, substituting (A.3) into (A.2), the first-order conditions are given in the usual fashion by differentiating $\mathrm{F}$ with respect to $\mathrm{x}_{\mathrm{i}}, \mathrm{b}_{\mathrm{h}}, \mathrm{b}_{\mathrm{h}}{ }^{*}$ and $\mathrm{m}_{\mathrm{h}}{ }^{*}$ and by equating the results to zero, i.e.,

$$
\begin{aligned}
& r u \alpha_{\mathrm{i}} / \mathrm{x}_{\mathrm{i}}-\mathrm{J}_{\mathrm{W}} \mathrm{P}_{\mathrm{i}} \mathrm{Q}=0, \quad \mathrm{i}=1,2, \\
& \mathrm{~J}_{\mathrm{W}} \mathrm{AW}+\mathrm{J}_{\mathrm{WW}}\left[\left\{-\alpha_{1} \sigma_{1} \mathrm{~b}-\alpha_{2} \sigma_{2} \mathrm{~b}+\sigma_{\mathrm{bb}} \mathrm{b}_{\mathrm{h}}+\sigma_{\mathrm{b}}{ }_{\mathrm{b}} \mathrm{b}_{\mathrm{h}}{ }^{*}\right.\right. \\
&\left.\left.+\sigma_{\mathrm{eb}}\left(\mathrm{m}_{\mathrm{h}}{ }^{*}+\mathrm{b}_{\mathrm{h}}{ }^{*}\right)\right\} \mathrm{W}^{2}\right]+\sum_{\mathrm{K}} \mathrm{J}_{\mathrm{WK}} \sigma_{\mathrm{Kb}} \mathrm{WK}=0, \\
& \mathrm{JW}_{\mathrm{W}} \mathrm{CW}+\mathrm{J}_{\mathrm{WW}}\left[( \sigma _ { \mathrm { b } } { } ^ { * } + \sigma _ { \mathrm { e } } ) \left\{-\alpha_{1} \sigma_{1}-\alpha_{2} \sigma_{2}+\sigma_{\mathrm{b}} \mathrm{b}_{\mathrm{h}}\right.\right. \\
&\left.\left.+\sigma_{\mathrm{b}}{ }^{*} \mathrm{~b}_{\mathrm{h}}{ }^{*}+\sigma_{\mathrm{e}}\left(\mathrm{m}_{\mathrm{h}}{ }^{*}+\mathrm{b}_{\mathrm{h}}{ }^{*}\right)\right\} \mathrm{W}^{2}\right]+\sum_{\mathrm{K}} \mathrm{J}_{\mathrm{WK}}\left(\sigma_{\mathrm{b}}{ }^{*} \mathrm{~K}+\sigma_{\mathrm{eK}}\right) \mathrm{WK}=0, \\
& \mathrm{~J}_{\mathrm{W} \mathrm{BW}}+\mathrm{J}_{\mathrm{WW}}\left[-\alpha_{1} \sigma_{1} \mathrm{e}-\alpha_{2} \sigma_{2 \mathrm{e}}+\sigma_{\mathrm{be}} \mathrm{b}_{\mathrm{h}}+\sigma_{\mathrm{b}}{ }^{*} \mathrm{~b}_{\mathrm{h}}{ }^{*}\right. \\
&\left.\left.+\sigma_{\mathrm{ee}}\left(\mathrm{m}_{\mathrm{h}}{ }^{*}+\mathrm{bh}^{*}\right)\right\} \mathrm{W}^{2}\right]+\sum_{\mathrm{K}} \mathrm{J}_{\mathrm{WK}} \sigma_{\mathrm{eK}} \mathrm{WK}=0,
\end{aligned}
$$


Yasunori Ishii : International Portfolios, Trade Imbalances and the Exchange Rate

$$
\mathrm{K}=\mathrm{P}_{1}, \mathrm{P}_{2}, \mathrm{P}_{\mathrm{b}}, \mathrm{P}_{\mathrm{b}} * \mathrm{E} .
$$

Thus, we obtain (8) in section II from these equations of (A.4).

\section{Notes}

(1) See D. Breeden (1979), D. Caves and E. Feige (1980), R. Clarida (1990), A. Fraga (1986), J. B. Macedo (1983), M. Mussa (1988), P. Neary (1988), A. C. Stockman and L. Svenson (1987), R. Stulz (1984), L. Svensson (1985) and their references, for example.

(2) For example, W. Branson and D. Henderson (1985), R. Clarida (1990), A. Fraga (1986) and J. Macedo, J. Goldsrein and D. Meerschwam (1988) have not considered monies, and R. E. Jr. Lucas (1982) and J. Macedo (1983) have not included bonds.

(3) In fact, Japan has continued a great deal of trade surplus for about the last two decades, but the exchange rate has not adjusted so as to attain the equilibrium of trade balance. Thus, it is recognized today that the exchange rate which is supposed to equilibrate trade balance of goods is generally different from that observed in international financial markets. As regard these arguments, see Matsumoto and et al. (1989), for example.

(4) J. Bergstrand (1991), W. Branson (1988), R. Clarida (1990), R. Driskill, M. Nelson and S. Steven (1992), J. Frankel (1988), J.. Frankel and A. Kenneth (1990), J. Macedo (1983), L. Svenson (1985) have indicated that PPP has lost its validity to explain the exchange rate movement.

(5) Many papers have adopted the assumptions of IRP and identical investors. However, R. Driskill, M. Nelson and S. Steven(1992) have presented some evidences of the investors' heterogeneous expectations, for example.

(6) See A. Fraga (1986), R. Hodrick (1990), Y. Ishii (1993) and R. Stulz (1984), for example, as the models of the general equilibrium analysis of the exchange rate based on the international portfolio approach.

(7) A bequest function with elasticity $\gamma$ with respect to terminal wealth does not change the results. A discount factor on instantaneous utility is also easily introduced. Finally $\mathrm{T}$ is supposed to be very large so that we may regard it as an approximately infinite horizon without losing the essential generality of our model.

(8) In this paper, since I concentrate on the investigations of relationships among the exchange rate, the investors' portfolio choices and the government policies in the home and foreign countries, the instantaneous flow of real noncapital income is assumed to be zero without losing the essential features of the results in this paper.

(9) Similarly, it is demonstrated that in the bonds models where only bonds are internationally traded the home and foreign bonds are always perfectly gross substitutive for each other.

(10) See W. Branson (1988), D. Papell (1989) and H. Yoshikawa (1990).

(11) See W. Branson (1988), D. Papell (1989) and H. Yoshikawa (1990) again.

\section{References}

Bergstrand, Jeffery H., 1991, "Structual Determinants of Real Exchange Rates and National Price Levels: Some Empirical Evidence”, American Economic Review 81, 325-334.

Branson, William H. and Dale W. Henderson, 1985, "Specification and Influence of Asset Markets", in 
Handbook of International Economics, Vol. II ed. by R. W. Jones and P. B. Kenen, Elsevier Science Publishers B. V..

1988, "Exchange Rate Policy after a Decade of "Float", in Exchange Rate Theory and

Practice ed. by Bilson, John F. O. and Richard C. Marston, University of Chicago Press.

Breeden, Douglas T., 1979, “An Intertemporal Asset Pricing Model with Stochastic Consumption and Investment Opportunities", Journal of Financial Economics 7, 265-296.

Caves, Douglas W. and Edgar L. Feige, 1980, "Efficient Foreign Exchange Markets and the Monetary Approach to Exchange-Rate Determination", American Economic Review 70, 120-134.

Clarida, Richard H., 1990, "International Lending and Borrowing in A Stochastic, Stationary Equilibrium", International Economic Review 31, 543-558.

Driskill, Robert , Nelson, Mark \& Steven, Sheffrin, 1992, "Some Evidence in Favor of A Monetary Rational Expectations Exchange Rate Model with Imperfect Capital Substitutability”, International Economic Review 33, 223-237.

Eaton, Jonathan and Stephen J. Turnovsky, 1983, "Exchange Risk, Political Risk, and Macroeconomic Equilibrium", American Economic Review 73, 183-189.

Flemming, Jhon S., Stephen J. Turnovsky and Murrary C. Kemp, 1977, "On the Choices of Numeraire and Certainty Prices in General Equilibrium Models of Price Uncertainty", Review of Economic Studies $44,573-583$.

Fraga, Arminio, 1986, "Price Uncertainty and The Exchange-Rate Risk Premium", Journal of International Economics 20, 179-185.

Frankel, Jeffrey A., 1988, "Tests of Monetary and Portfolio Balance Models of Exchange Rate Determination", in Exchange Rate Theory and Practice ed. by Jhon F. O. Bilson and Richard C. Marston, University of Chicago Press.

and Kenneth A. Froot, 1990, "Chartists, Fundamentalists, and Trading in the Foreign Exchange Market”, American Economic Review 80, pp. 181-183.

Frenkel, Jacob A., 1988, Comments, in Exchange Rate Theory and Practice ed. by Bilson, John F. O. and

Richard C. Marston, University of Chicago Press.

Helpman, E., 1987, “Exchange Rate Management: Intertemporal Tradeoffs", American Economic Review 77, 107-123.

Hodric, Robert J., 1990, "Volatility in the Foreign Exchange and Stock Markets: Is it Excessive", American Economic Review 80, 181-183. , 1977, “On the Theory of Competitive Firm Under Price Uncertainty: Note”, American Economic Review, 67, 768-769.

Ishii, Yasunori, 1986, "Asymmetric Technological Uncertainty and International Trade in the Presence of Risk-Sharing Arrangements", Journal of Economics, 46, 267-283.

ב 1986, "On the Theory of International Trade Between Capitalist and Labor-Managed Countries", Economics Letters, 21, 195-198.

1990, "Measures of Risk Aversion and Comparative Statics of Industry Equilibrium : Correction", American Economic Review, 79, 285-286.

1990, “On the Theory of East-West Trade Under Uncertainty", Journal of Economics, 52, 267-283. 
Yasunori Ishii : International Portfolios, Trade Imbalances and the Exchange Rate 1993, International Portfolios, Trade Imbalances and the Exchange Rate, Discussion Paper

Series No. 53, Yokohama City Univercity.

Kouri, Pentti J.K., 1988, “Comments" in Exchange Rate Theory and Practice ed. by John F. Bilson and Richard C. Marston, University of Chicago Press.

Lucas, Robert E. Jr. 1982, "Interest Rates and Currency Prices in a Two-Country World", Journal of Monetary Economics 10, 335-359.

Macedo, Jorge B., 1983, "Optimal Currency Diversification For A Class of Risk-Averse International Investers", Journal of Economic Dynamics and Control 5, 173-185.

Jeffrey A. Goldstein \& David, M. Meerschwam, 1988, “International Portfolio Diversification :

Short-Term Financial Assets and Gold", in Exchange Rate Theory and Practice ed. by John F. O.

Bilson \& Richard C. Marston, University of Chicago Press.

Merton, Robert C., 1971, "Optimum Consumption and Portfolio Rules in a Continuous Time Model", Journal of Economic Theory 3, 373-413.

Mussa, Michael, 1988, "The Theory of Exchange Rate Determination", in Exchange Rate Theory and Practice ed. by John F. Bilson and Richard C. Marston University of Chicago Press.

Neary, Peter, 1988, "Determinants of the Equilibrium Real Exchange Rate", American Economic Review 78, 210-215.

Obstfeld, Maurice, 1986, “Capital Controls, The Dual Exchange Rate, and Devaluation", Journal of International Economics 20, 1-20.

Papell, D. H., 1989, “Monetary Policy in the United States Under Flexible Exchange Rates”, American Economic Review 79, 1106-1116.

Stockman, Alan C. and Lars O. Svensson, 1987, "Capital Flow, Investment, and Exchange Rate", Journal of Monetary Economics 19, 171-201.

Stulz, Renè M., 1984, "Currency Preferences, Purchasing Power Risk, and the Determination of Exchange Rates in an Optimizing Model”, Journal of Money, Credit, and Banking”, 16, 302-316.

Svensson, Lars O.,1985, "Currency Prices, Terms of Trade, and Interest Rates", Journal of International Economics 18, 17-41.

Yoshikawa, Hiroshi, 1990, “On the Equilibrium Yen-Dollar Rate”, American Economic Review 80, 576-583. 